$\xi^{2}=$

\title{
Petrographic and geochemical interpretations of source provenance and tectonic setting of the Lokoja Sandstone, Bida Basin, Nigeria
}

\author{
G. U. Ozulu ${ }^{1 *}$, A. U. Okoro² ${ }^{2}$ V. O. Ndubueze ${ }^{3}$ \\ ${ }^{1}$ Department of Earth Sciences, Salem University P.M.B. 1060 Lokoja, Kogi State, Nigeria \\ ${ }^{2}$ Department of Geological Sciences, Nnamdi Azikiwe University P.M.B. 5025 Awka, Anambra State, Nigeria \\ ${ }^{3}$ Department of Energy \& Petroleum Studies, Novena University Ogume, P.M.B. 02 Kwale, Delta State, Nigeria \\ *Corresponding author E-mail:georgeozulu@yahoo.com george.ozulu@salemuniversity.edu.ng
}

\begin{abstract}
The petrography and geochemistry of major and trace elements distribution pattern for the Lokoja Sandstones, Southern Bida Basin, Nigeria; were used to interpret their provenance, weathering conditions and paleotectonic setting. A total of seven (7) representative sandstone samples were selected for petrographic, heavy minerals and inorganic geochemical analyses; that is X-ray diffraction (XRD), X-ray fluorescence (XRF) and Laser ablation-inductively coupled plasma-mass spectrometry (LA-ICP-MS). Results of the petrographic analysis showed $52.14 \%$ quartz, $39.29 \%$ feldspar, $2.00 \%$ rock fragments, $5.14 \%$ matrix and cement fraction as well as $1.43 \%$ unfilled voids. Results of major elements and oxides suggests intermediate to felsic source rocks while the dominance of Na-rich feldspar to the k-feldspar and high value of $\mathrm{Fe} 2 \mathrm{O} 3+\mathrm{MgO}$ shows contribution from ferromagnesian minerals of mafic igneous source provenance and oceanic island arc region. Average concentrations of designated trace elements in the studied sandstones are low in concentrations. The lower concentrations of $\mathrm{Cr}$, $\mathrm{Co}$, and $\mathrm{Ni}$ and higher concentrations of $\mathrm{Zr}$, Ba, and $\mathrm{Sr}$ suggest a felsic progenitor rock. But significantly high values of $\mathrm{Ni}$ (7.02 ppm), La/Co (7.99), and Ni/Co (3.28) as well as the low concentration value of Y, (3.23 ppm) suggests contributions from mafic source rocks. Low average ratios for $\mathrm{La} / \mathrm{Co}, \mathrm{Th} / \mathrm{Co}, \mathrm{Th} / \mathrm{Sc}, \mathrm{Ni} / \mathrm{Co}, \mathrm{Cr} / \mathrm{Ni}, \mathrm{Cr} / \mathrm{Sc}, \mathrm{Cr} / \mathrm{Th}, \mathrm{Ni} / \mathrm{Co}, \mathrm{Cr} / \mathrm{Ni}, \mathrm{Cr} / \mathrm{Th}, \mathrm{Cr} / \mathrm{Sc}$, $\mathrm{Th} / \mathrm{Sc}, \mathrm{La} / \mathrm{Co}$ and $\mathrm{Th} / \mathrm{Co}$ also suggest a felsic source provenance. An average CIA value of $78.04 \%$ is indicative of an intense recycling in the source area while an average MIA value of $56.13 \%$ suggests a moderate degree of weathering. The high clay matrix and feldspar content have been used to classify the sandstones as feldspathic greywackes deposited in dry arid climatic conditions under a basement uplifted tectonic setting.
\end{abstract}

Keywords: Geochemistry; Lokoja Sandstone; Petrography; Provenance; Tectonic Setting.

\section{Introduction}

The Bida Basin is one of Nigeria's inland sedimentary basins, which is situated in the central part of Nigeria. This basin has variously been studied by workers like Adeleye (1974, 1975), Jan du Chene et al. (1978), Mebradu et al. (1986), Ojo, S. B. and Ajakaiye (1989), Braide (1992a \& 1992b), Ojo, O. J. (1992, 2009, 2012), Idowu and Enu (1992), Ladipo et al. (1994), Olaniyan and Olobaniyi (1996), Akande et al. (2005), Ehinola, et al. (2006), Okoro (2007), Obaje et al. (2004, 2006, 2011, 2013, 2015). Most of these studies concentrated on the stratigraphy/biostratigraphy, basin geometry and facies analysis and hydrocarbon potentials with little attention given to the petrofacies, geochemistry, provenance and tectonic setting of the sedimentary fill. Nton and Adamolekun (2016) integrated sedimentological and geochemical data from the Lokoja and Patti Formations to deduce the provenance, palaeo-depositional characteristics and tectonic history of the sediments. The study concluded that the sediments were sourced from the adjacent felsic rocks within the southwestern and north-central basement complex of Nigeria and were deposited in a fluvial setting. Madukwe et al. (2014) used petrography and major and trace elements geochemistry to interpret the provenance and tectonic settings of the Lokoja Sandstones. They concluded that the sandstones were mainly mature lithic arenites, subgreywackes and protoquartzites derived from felsic igneous rocks within oceanic Island Arc setting. Noting the difference in rock types, climatic conditions and tectonic settings, interpreted by previous authors (Madukwe et al. 2014; and Nton and Adamolekun, 2016); this paper focussed on petrography and geochemistry, using major and trace elements to re-evaluate and classify the sandstones of the Lokoja Formation and interpret their provenance and tectonic setting.

Provenance studies are key elements of any basin analysis as it provides basic information regarding their tectonic origin (Miall, 2000; Sanni et al. 2016). Bhatia (1983); Bhatia and Crook (1986); Roser and Korsch (1986) used the chemical compositions of sandstones to discriminate their tectonic settings. Dickinson and Suczek, (1979) used framework composition to classify sandstone suites into three tectonic provenances, viz: continental block provenances, where sediments sources are shields and platform faulted basement blocks in craton interior, as well as transitional and uplifted basements. The other is magmatic arc provenance where sediments sources are active Island Arc orogens or active continental margins. They comprise un-dissected, transitional and dissected provenances while the last is the 
recycled orogen provenance, where sediments sources are deformed with uplifted stratal sequences in subduction zones along collision orogens or within foreland fold-thrust belts (Dickinson and Suczek, 1979; Dickinson, 1985; Igwe et al. 2013).

This study focussed on petrography and geochemistry of major and trace elements of the Lokoja sandstones, Southern Bida Basin; using data from mineralogy and elemental distribution pattern to interpret the provenance and tectonic setting of the sandstones.

\section{Geological setting of the bida basin}

The geologic setting and origin of the Bida Basin is controversial and has been a subject of discussion over the years. The Bida Basin is a NW-SE trending inland basin, stretching from Shegwa in Niger State to Dekina in Kogi State (Rahaman et al. 2019). It is situated between the Precambrian Northern Nigeria Massif and the West African Craton (Braide, 1992b). This basin merges with the Anambra and Sokoto basins in terms of its sedimentary fill in the SE and NW ends respectively (Adeleye, 1974, Ladipo, 1988, Ojo, 2009, and Obaje et al. 2011). While Ojo and Ajakaiye (1989) estimates the areal coverage of the basin as about 7,000 $\mathrm{km}^{2}$, stretching extensively from the confluence of the Niger-Benue Rivers in the north-western part of Nigeria with a maximum width in the middle Niger area at $160 \mathrm{~km}$. Zaborski (1998) is of the opinion that the basin is approximately $350 \mathrm{~km}$ in its longest axis and varies from 75 to $150 \mathrm{~km}$ in width (fig. 1). Gravity studies put the maximum thickness of the sedimentary successions at about $3.5 \mathrm{~km}$ in the central axis (Ojo, 1984). Benkhelil (1989 and Obaje et al. (2011) believe that the basin is a gently down-warped trough whose origin is closely related to the Benue Trough and part of the West and Central African Rift System.

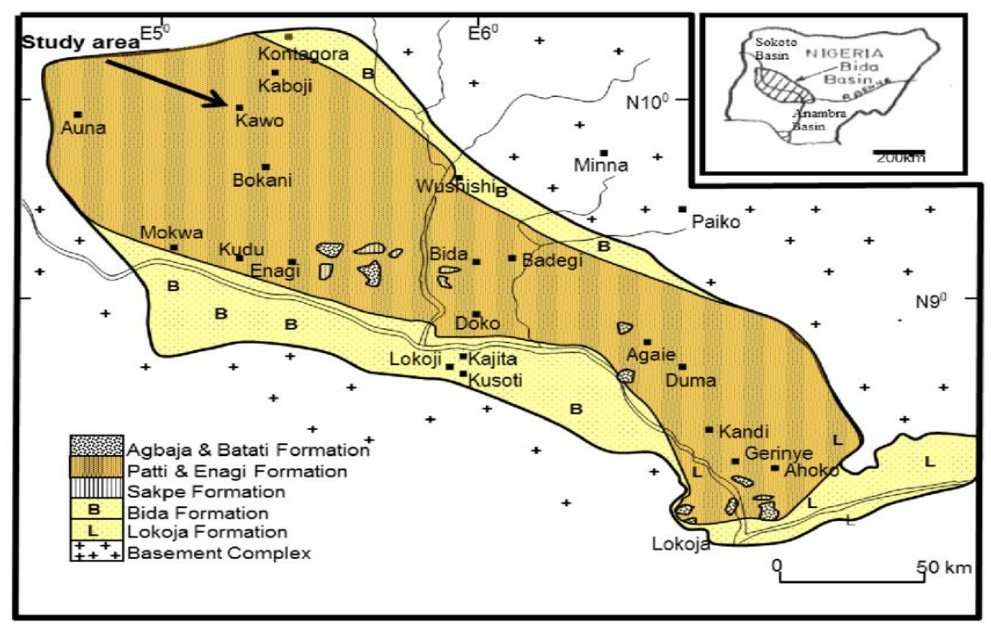

Fig. 1: Simplified Geological Map of the Bida Basin (After Braide, 1992c).

Three tectonic models have been proposed for the origin of the Bida Basin. Firstly is the Rift model, where the basin is described as a rift bounded, tensional structure that produced an aulacogen (a failed rift) during the opening of the South Atlantic Ocean and separation of African and South American plates (Wright, 1968; Grant, 1971; Burke et al. 1970, 1971; Adeleye, 1973; Kogbe et al. 1981; Adeniyi, 1984; Agyingi, 1993). Landsat imageries of the basin indicated that the basin is controlled by NW-SE trending faults in the surrounding basement (Kogbe et al. 1981). This is further subdivided into three major sets oriented in N-S, NE-SW and NW-SE direction. Agyingi (1993) suggests a post-Santonian origin as sediments in the basin are seen to be generally undisturbed. Likkason (1993), however, believed that the basin formed from a mantle plume located at the south-eastern part of the basin close to the confluence between the Benue and Niger rivers.

In the second model, the Simple Sag model; Whiteman (1982) disagrees with the aulacogen (triple rift system) based on the structural features. He submits that the basin is probably a Campanian-Maastrichtian feature in origin and that the sedimentation in the basin actively started during the Late Campanian transgression. He thus suggested a simple Post-Santonian intra-cratonic sag and pull-apart basin. Ojo, S. B. and Ajakaiye, (1989) support the isostatic subsidence hypothesis based on the great differences in width of the basin. Their support for the isostatic subsidence hypothesis is also coupled with the fact that major phenomena associated with rifts such as volcanism, igneous intrusions, major faulting and intermittent uplifts; are conspicuously absent in the basin. The basin is thought to be associated with isostatic readjustments and gentle down-warping or subsidence of the granitic Basement Complex as a result of the removal of mantle materials during the emplacement of the Younger Granite Ring Complexes in the Jurassic (Whiteman, 1982; Ojo, S. B. and Ajakaiye, 1989).

The third model is the Wrench Fault/Srike-Slip Tectonic model advanced to explain the origin of the Bida Basin (Braide, 1990, 1992b). It is considered as a graben resulting from the sinistral movements along the bounding Chain and Charcot fracture systems of the Benue Trough.The basin formed as a pull-apart basin with multiple phases of transtension and basin infilling with little internal deformation and irregular bottomed basin floor of graben and horst structures (Braide, 1990, 1992a).It is thought to have developed at an angle to the major principal fault movements in which the horizontal movements translated to vertical movements leading to basement fragmentations (Benkhelil, 1989 and Braide, 1990, 1992b).

The tectonics responsible for the basin genesis seems to be closely connected with the Santonian orogenic movements of south-eastern Nigeria in the Benue Trough (Adeleye 1989; Kogbe, 1989). Wright et al. (1985) and Ojo, and Ajakaiye, (1989); while agreeing with the cratonic sag model proposition, suggested that a rift origin may not be ruled out. A generally held opinion, however, is that the basin originated as a simple intracratonic sag basin (Okoro, 2007).Based on the fact that there are no clear evidences of rifts associated activities such as volcanism, igneous intrusions, major faulting and intermittent uplifts in the basin, the simple intracratonic sag model seems more plausible. 


\section{Method of study}

The methods of investigation involved both field study and laboratory analyses. Preliminary megascopic identification of minerals in rocks was done in the field while the laboratory analyses included those for mineralogical studies - [petrography and heavy minerals analysis]and inorganic geochemistry - [X- ray diffraction (XRD), X-ray fluorescence (XRF) and Laser ablation-inductively coupled plasma-mass spectrometry (LA-ICP-MS)].

\subsection{Mineralogical studies}

a) Petrographic Analysis

A total of seven (7) representative sandstone samples were selected for petrographic analysis. The procedures described by Sorby, (1882) and cited in Reed and Mergner, (1945) were followed for the petrographic analysis. Seven thin sections were prepared and studied using petrographic microscopes for minerals identification under plane polarized light (PPL) and cross polarized light (XPL). Sandstone classification was done using the ternary diagram for mineral-based apexes of quartz (Q), feldspar (F) and rock (RF) after Folk, (1974) and Pettijohn, (1975).

b) Heavy mineral analysis

A total of seven (7) representative sandstone samples processed for their heavy mineral composition. The method used for the heavy mineral separation was the gravity settling method as prescribed by Milner, (1962) and the heavy minerals were identified using a reflecting microscope. The Zircon, Tourmaline, Rutile (ZTR) Index was calculated using the percentage of the combined zircon, tourmaline and rutile grains for each sample (Hubert, 1962).

c) X-ray diffraction (XRD) analysis

The X-Ray diffraction (XRD) was used for bulk mineral and clay mineral analysis of the sandstones. A Philips PANalytical instrument with a pw $3830 \mathrm{X}$-ray generator operated at $40 \mathrm{kV}$ and $25 \mathrm{~mA}$ was used for this analysis. The pulverized samples were oven dried at 100 ${ }^{\circ} \mathrm{C}$ for 12 hours to remove the adsorbed water. The samples were pressed into rectangular aluminium sample holders using an alcohol wiped spatula and then clipped into the instrument sample holder. The samples were then scanned on 2 theta scale at intervals of 0.02 sec and counted for $0.5 \mathrm{sec}$ per step from 5 to 85 degrees. The XRD machine generated only intensity plot as a function of $2 \theta$ while the diffraction patterns recorded by XRD machine were like a "fingerprint" of crystalline materials and compared with standard patterns for identification of unknown materials. Results of this analysis are reflected in the $\mathrm{x}$-ray diffractogram showing the spectra signatures of the minerals present.

\subsection{Geochemical analysis}

The inorganic geochemistry was done by X-ray fluorescence (XRF) and laser ablation-inductively coupled plasma-mass spectroscopy (LA-ICP-MS)

a) X-ray fluorescence (XRF) analysis

X-ray fluorescence (XRF) was carried out on seven (7) sandstone samples to determine their major elements composition. The sandstone samples were pulverized and analyzed using the Philips Empyrean PANalytical Machine with a $2.4 \mathrm{~kW}$ Rh X-ray tube. In the analytical procedures for major element analysis, $1.00 \mathrm{~g}$ of the sample was weighed and placed in the oven at $110^{\circ} \mathrm{C}$ to dry for 1 hour. $10.00 \mathrm{~g}$ Claisse flux was then added and fused in the Claisse fluxer for 23 minutes. $0.2 \mathrm{~g}$ of $\mathrm{Na}_{2} \mathrm{CO}_{3}$ was then added to the mix. You now have the sample + flux $+\mathrm{Na}_{2} \mathrm{CO}_{3}$ pre-oxidized at $700{ }^{\circ} \mathrm{C}$ before fusion. The flux type employed was Ultrapure Fused Anhydrous LiTetraborate-Li-Metaborate $\left(66.67 \% \mathrm{Li}_{2} \mathrm{~B}_{4} \mathrm{O}_{7}+32.83 \% \mathrm{LiBO}_{2}\right)$ and a releasing agent, Li-Iodide $(0.5 \% \mathrm{LiI})$. The technique reports major elements concentration as percentage $(\%)$ oxides. This analytical method yielded data for ten (10) major elements - [Silicon (Si), Aluminium (Al), Iron (Fe), Calcium (Ca), Magnesium (Mg), Potassium (K), Sodium (Na), Titanium (Ti), Manganese (Mn) and Phosphorus $(\mathrm{P})]$, as oxides percentages.

b) Laser ablation-inductively coupled plasma-mass spectroscopy (LA-ICP-MS)

Laser ablation-inductively coupled plasma-mass spectrometry (LA-ICP-MS) analysis was carried out also on the seven (7) sandstone samples to determine their trace elements composition using the Analytik Jena Varian ICP-MS machine. LA-ICP-MS is a sensitive analytical technique for multi-elemental analysis where the laser is used to vaporize the surface of the solid sample. The vapour from the surface of the solid sample and other particles are then transported by the carrier gas flow to the ICP-MS and the trace element compositions reported in parts per million ( $\mathrm{ppm}$ ). In the experimental method called the pressed pellet method for trace elements analysis, $8 \mathrm{~g}$ of milled powder was weighed and mixed thoroughly with 3 drops of Mowiol wax binder. The pellets were then pressed with pill press to 15 ton pressure and dried in the oven at $100{ }^{\circ} \mathrm{C}$ for 30 minutes before analyzing. This method yielded data for eighteen (18) trace elements -[Lead ( $\mathrm{Pb})$, Arsenic (As), Cadmium (Cd), Chromium (Cr), Thorium (Th), Copper (Cu), Nickel (Ni), Scandium (Sc), Cobalt (Co), Yttrium (Y), Mercury (Hg), Barium (Ba), Calcium (Ca), Latium (La), Strontium (Sr), Zirconium (Zr), Zinc (Zn) and Phosphorus (P)], reported as $\mathrm{mg} / \mathrm{kg}(\mathrm{ppm})$.

c) Loss on ignition

Loss on ignition (LOI) is a test where samples of the material being analyzed are strongly heated at a specified temperature, thereby allowing volatile substances to escape. Oxygen is added until its mass ceases to change. The prepared samples were oven-dried overnight at specified temperature $\left(105^{\circ} \mathrm{C}\right)$, to determine their natural moisture contents. The samples were then placed overnight again in an oven at another specified temperature $\left(800{ }^{\circ} \mathrm{C}\right)$ and the difference in weight was determined to obtain the Loss on ignition (LOI). The LOI consists of contributions from the volatile compounds of $\mathrm{H}_{2} \mathrm{O}, \mathrm{OH}^{-}, \mathrm{CO}_{2}, \mathrm{~F}^{-}, \mathrm{Cl}^{-}, \mathrm{S}$; in parts also $\mathrm{K}^{+}$and $\mathrm{Na}^{+}$(if heated for too long); or alternatively added compounds of oxygen $\left(\mathrm{O}_{2}\right)$ by oxidation, e.g. ( $\mathrm{FeO}$ to $\left.\mathrm{Fe}_{2} \mathrm{O}_{3}\right)$, and later carbon-dioxide $\left(\mathrm{CO}_{2}\right)$, e.g. $(\mathrm{CaO}$ to $\mathrm{CaCO} 3)$.

\section{Results}

\subsection{Petrology and mineralogy}

Result of the petrographic analysis show quartz and feldspar as the dominant minerals with some lithic (rock) fragments as framework elements. Photomicrographs for the petrographic analysis are shown in figs. 2-8, while petrographic analysis data and summary of the mineralogical composition for the sandstone samples is presented in tables $1 \mathrm{a} \& 1 \mathrm{~b}$. The void-filling minerals consist of clay, iron oxide 
and silt/clay size quartz and mica. The matrix is composed of unrecrystallised clay and silt size quartz while iron oxide act as the binding cement. Majority of the quartz minerals display straight to undulose extinction, under cross polarized light; while the margins of most individual quartz grains are fractured and have sutures, indicative of tectonic activities. Some plagioclase minerals are untwined making them difficult to differentiate from each other and from quartz as well.

(A)

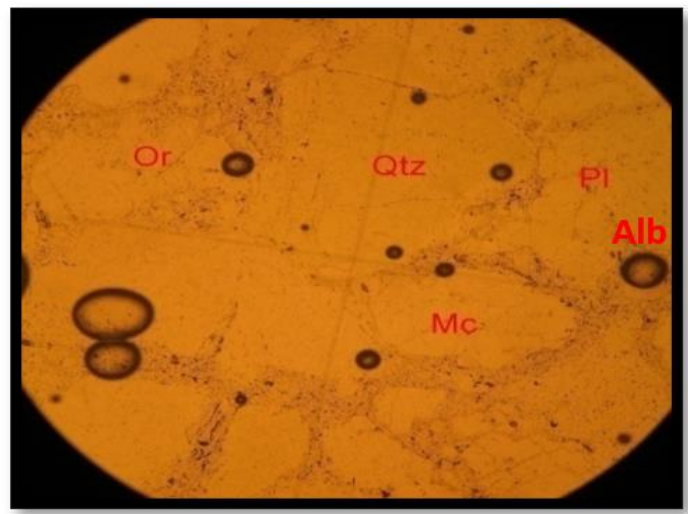

(B)

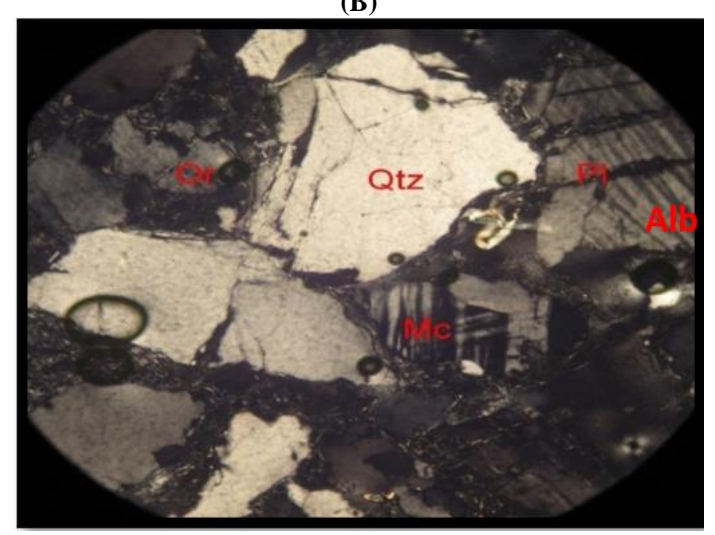

Fig. 2:Photomicrograph of LKJ 1 Sandstone Sample - (A) PPL and (B) XPL, Showing Sub-Rounded Quartz, Microcline, Albite and Orthoclase Feldspar.

(A)

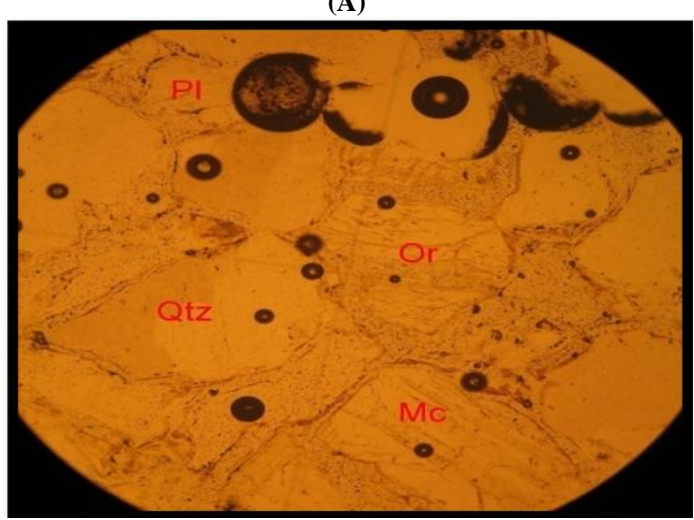

(B)

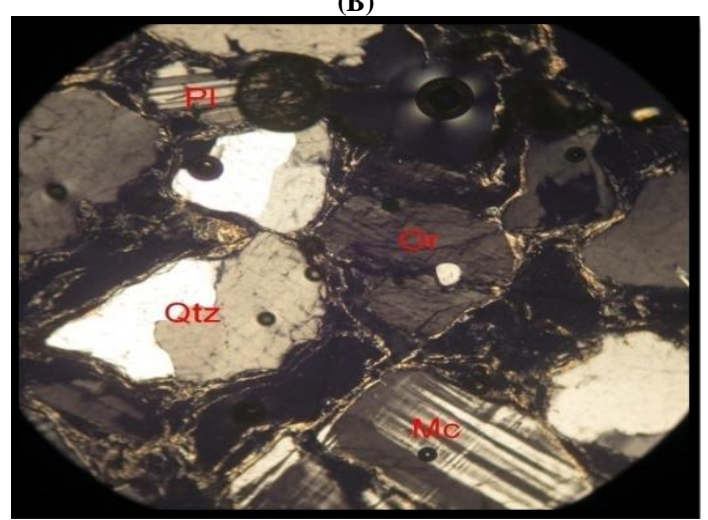

Fig. 3:Photomicrograph of LKJ 2 Sandstone Sample - (A) PPL and (B) XPL Showing Sub-Rounded Quartz, Microcline, Plagioclase and Orthoclase Feldspar.

(A)

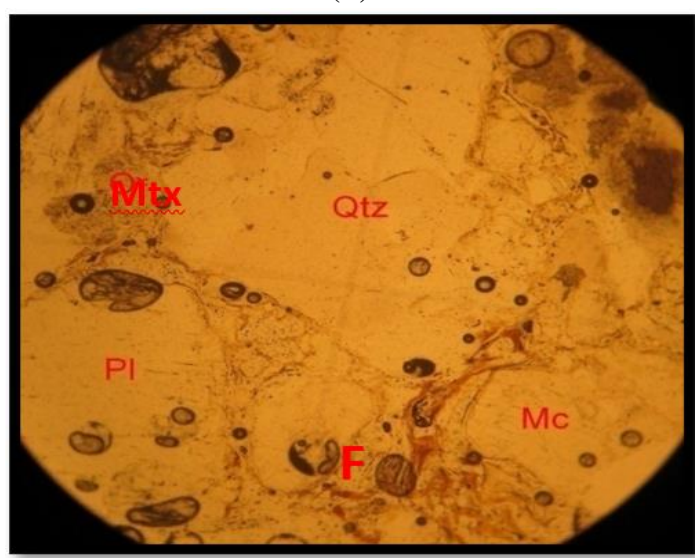

(B)

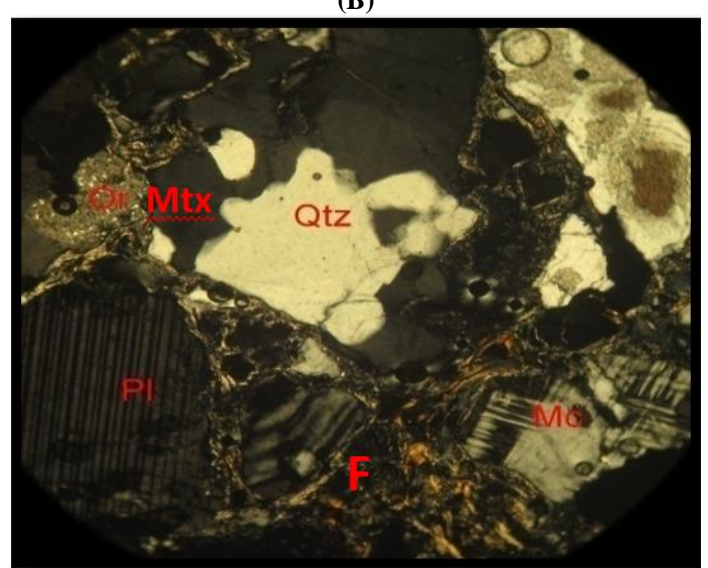

Fig. 4:Photomicrograph of LKJ 3 Sandstone Sample - (A) PPL and (B) XPL Showing Sub-Rounded Quartz, Microcline, Plagioclase and Orthoclase Feldspar. 

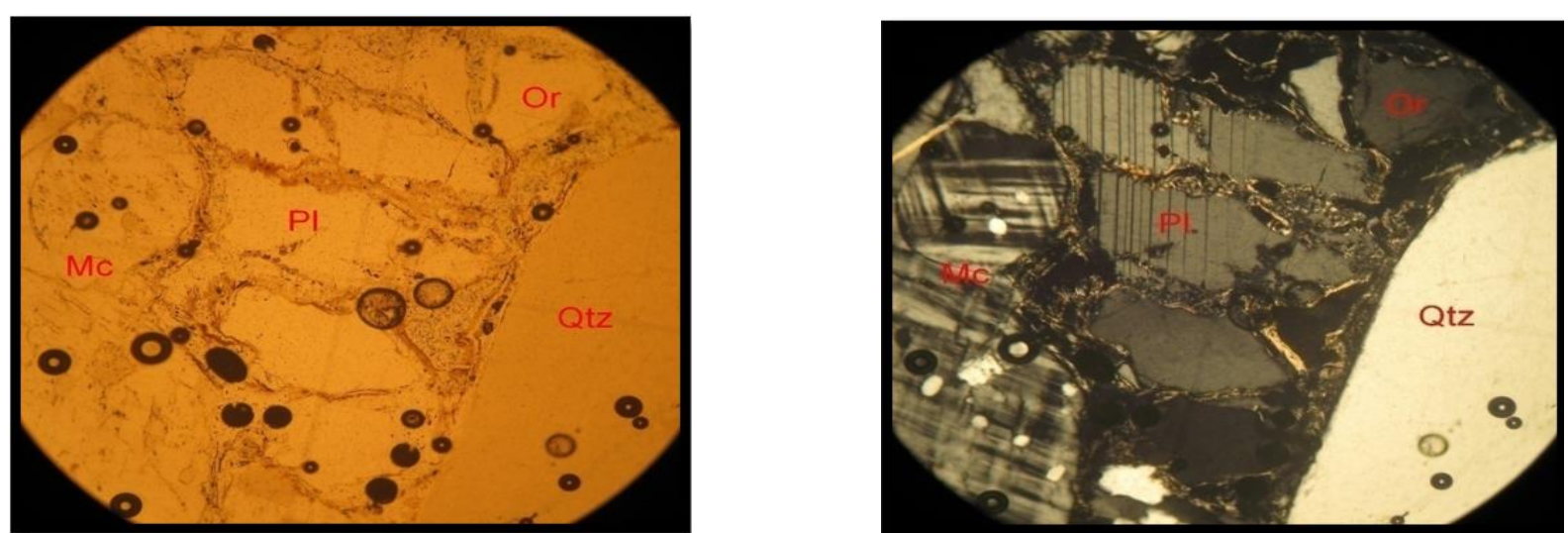

Fig. 5:Photomicrograph of LKJ 4 Sandstone Sample - (A) PPL and (B) XPL Showing Sub-Rounded Quartz, Microcline, Plagioclase and Orthoclase Feldspar.

(A)
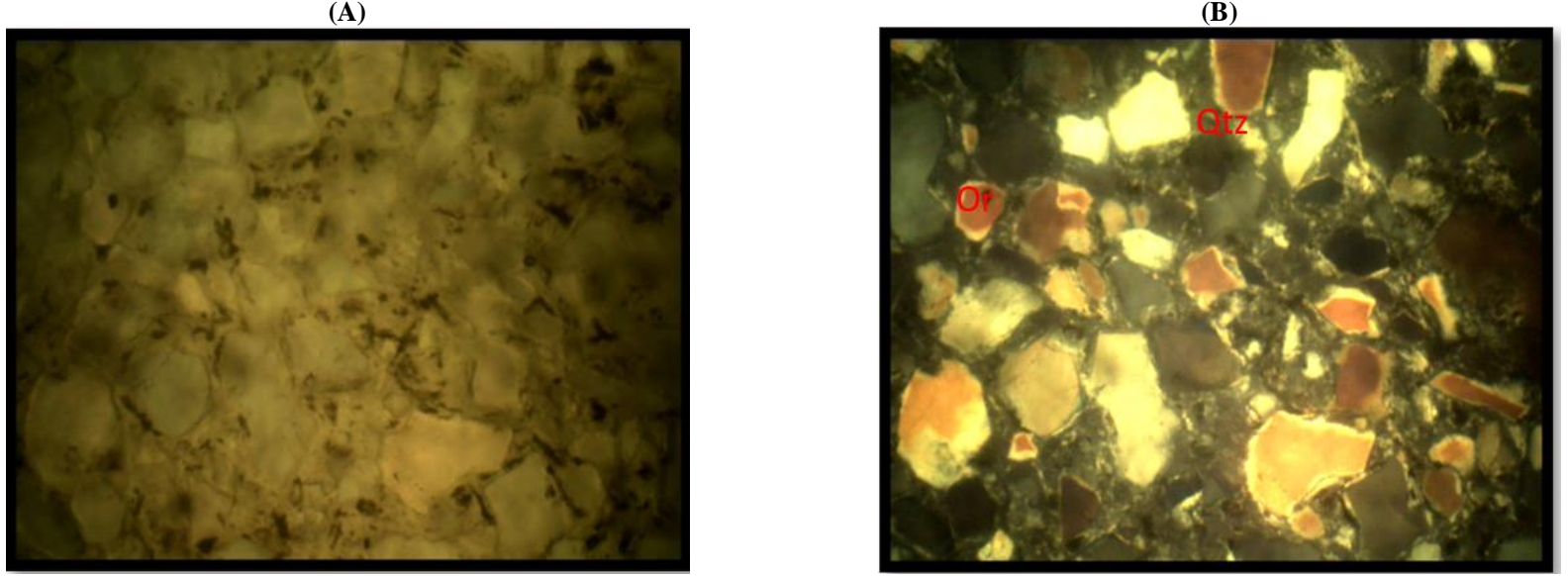

Fig. 6:Photomicrograph of LKJ 5 Sandstone Sample - (A) PPL and (B) XPL Showing Sub-Rounded Quartz, Microcline, Albite and Orthoclase Feldspar.

(A)

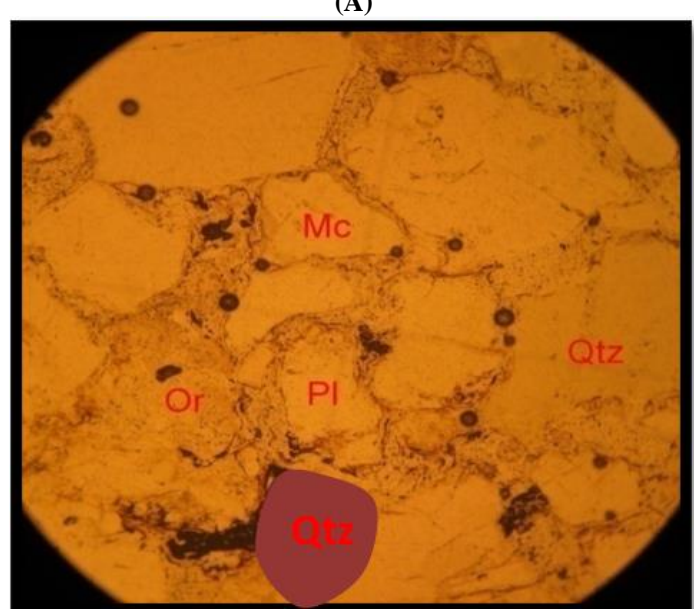

Fig. 7:Photomicrograph of LKJ 6 Sandstone Sample -

(A)

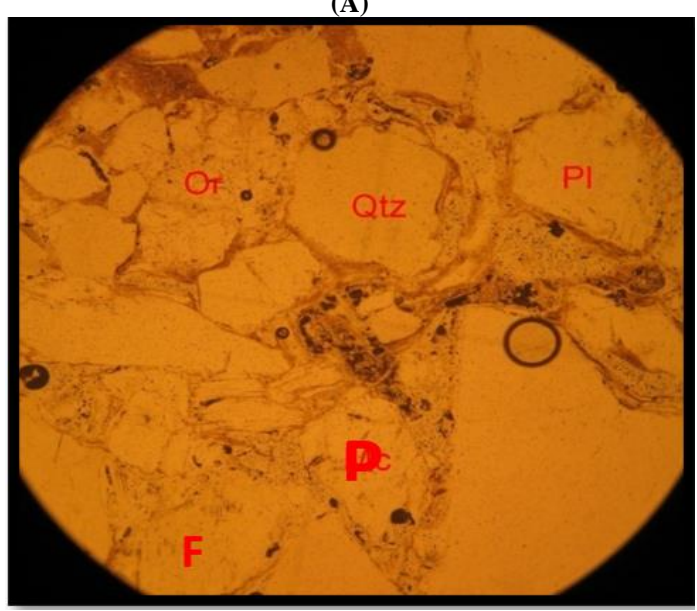

(B)

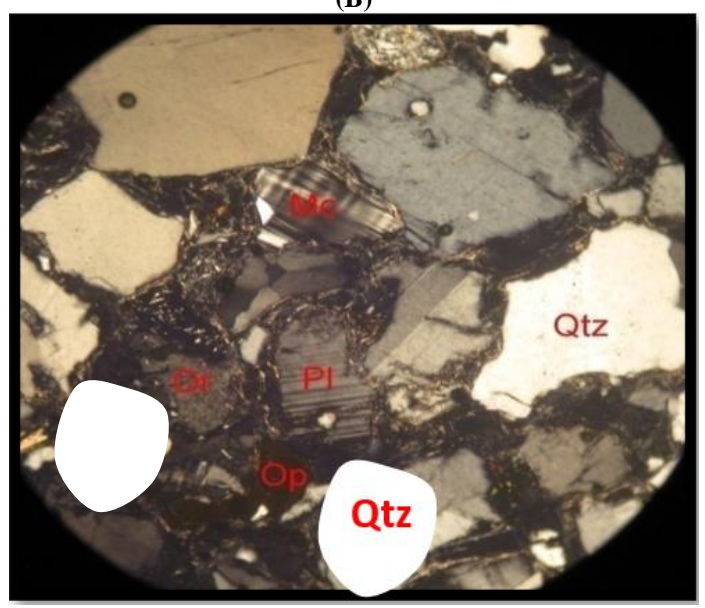

- (A) PPL and (B) XPL Showing Sub-Rounded Quartz and Feldspar.

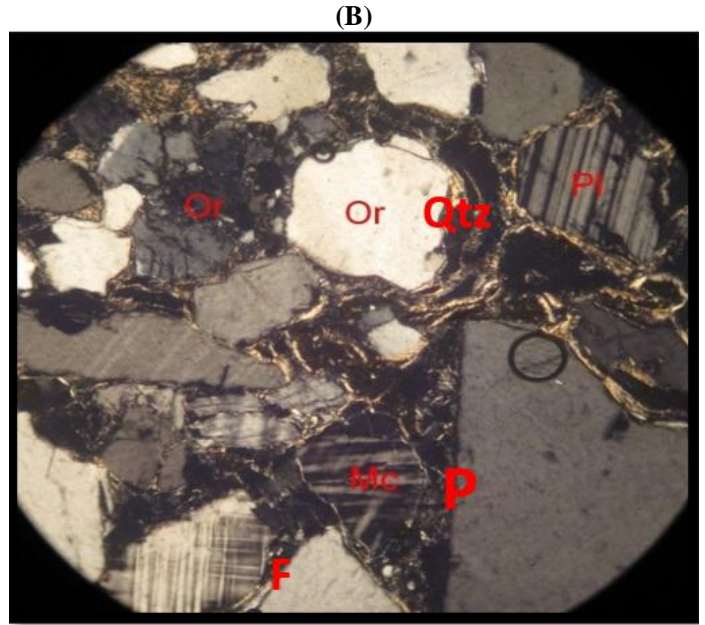


Fig. 8:Photomicrograph of LKJ 7 Sandstone Sample - (A) PPL and (B) XPL Showing Sub-Rounded Quartz and Feldspar.

Key: Qtz - Quartz, Or - Orthoclase, Pl - Plagioclase, Mc - Microcline, Alb - Albite, and Mtx - Matrix

Tables $1 \mathrm{a}$ and $1 \mathrm{~b}$ show the modal composition of the sandstones and detrital framework composition respectively. Quartz vary from 36.81- $46.67 \%$ with an average of $42.42 \%$, feldspar from $28.58-37.36 \%$ with an average of $32.44 \%$, rock fragments from $3.13-4.42 \%$ with an average of $3.72 \%$, matrix and cement from $15.32-20.33 \%$ with an average of $17.96 \%$, while unfilled voids vary from $2.10-4.43 \%$ with an average of $3.47 \%$. Monocrystalline quartz constitutes about $90 \%$ of the total quartz while the polycrystalline quartz is $10 \%$.

Table 1: A) Petrographic Analysis Data Showing Total Composition of Sandstone in the Study Area (\%)

\begin{tabular}{|c|c|c|c|c|c|}
\hline Sample No. & Quartz\% & Feldspar\% & Rock Fragments\% & Matrix \& Cement $\%$ & Unfilled Void\% \\
\hline LKJ 1 & 41.76 & 37.36 & 3.46 & 15.32 & 2.10 \\
\hline LKJ 2 & 36.81 & 35.71 & 4.42 & 18.63 & 4.43 \\
\hline LKJ 3 & 37.77 & 35.00 & 4.07 & 19.64 & 3.56 \\
\hline LKJ 4 & 41.67 & 29.76 & 4.08 & 20.33 & 4.16 \\
\hline LKJ 5 & 46.67 & 29.70 & 3.45 & 17.13 & 3.05 \\
\hline LKJ 6 & 46.42 & 28.58 & 3.42 & 18.24 & 3.34 \\
\hline LKJ 7 & 45.84 & 30.95 & 3.13 & 16.42 & 3.66 \\
\hline Average Value & 42.42 & 32.44 & 3.72 & 17.96 & 3.47 \\
\hline
\end{tabular}

Key: LKJ 1 - Felele, LKJ 2 - Felele, LKJ 3 - Nataco, LKJ 4 - Nataco, LKJ 5 - Oworo Estate, LKJ 6 - Banda, LKJ 7 - Banda.

Table 1: B) Summary of Mineralogical Composition of Sandstone Samples (\%) from Re-Calculated Framework of the Sandstone Samples for Study Area.

\begin{tabular}{|c|c|c|c|c|}
\hline Sample Nos. & Quartz & Feldspar & Rock Fragments & MMI \\
\hline LKJ 1 & 50.57 & 45.24 & 4.17 & 1.02 \\
\hline LKJ 2 & 47.84 & 46.41 & 5.74 & 0.92 \\
\hline LKJ 3 & 49.15 & 45.55 & 5.30 & 0.97 \\
\hline LKJ 5 & 58.47 & 37.21 & 4.32 & 1.41 \\
\hline LKJ 6 & 59.19 & 36.44 & 4.36 & 1.45 \\
\hline LKJ 7 & 57.36 & 38.73 & 3.92 & 1.34 \\
\hline $\begin{array}{l}\text { Average } \\
\text { Value }\end{array}$ & 53.98 & 41.28 & 4.73 & 1.17 \\
\hline
\end{tabular}

\subsubsection{Textural and mineralogical maturity}

Two lines of interpretation, (textural and mineralogical maturity), have been used to describe the composition of the Lokoja Sandstones. Textural maturity was evaluated on the basis of Folk, (1974) and PettiJohn, (1975) textural maturity flow charts. Table 1a shows that the sandstones contain average matrix (clay) and cement percentage of $17.96 \%$ which is $>15 \%$. Therefore the Lokoja Sandstone is interpreted as texturally immature based on poor sorting and clay content of over 5\% (Folk, 1974). The sandstones classification scheme of PettiJohn, (1975) and Bogg (2006) recognizes the importance of matrix in subdividing sandstones into the arenite and wacke clans. Sandstones with less than $15 \%$ belong to the arenite clan while those with $15 \%$ or more matrixes belong to the wacke clan. Matrix is a textural parameter which affects the porosity of the sandstone and reflects the fluidity of the transporting medium (Pettijohn, 1975). The average matrix content of over $15 \%$ in the Lokoja Sandstones suggests that they belong to the wacke clan. The re-calculated framework composition with an average feldspar of $41.28 \%$ (table 1b), classifies the sandstones as feldspathic (arkosic) wacke (fig. 9a). However on the basis of Folk (1974) classification scheme, which completely discards matrix as an important element in sandstone classification, the Lokoja Sandstone is classified as an arkosic or feldsparthic arenite (fig. 9b).

The mineralogical maturity was deduced using the mineralogical maturity index (MMI) of Nwajide and Hoque, (1985). The mineralogical maturity index (MMI) values of the Lokoja Sandstone, range from $0.92-1.45$ with an average of 1.17 (table $1 \mathrm{~b}$ ). Since MMI value is $<3.0$ but $>1.0$, the sandstones are interpreted to be mineralogically immature. Mineralogically, the Lokoja sandstone averagely comprises $42.42 \%$ quartz, $32.44 \%$ feldspar, $3.72 \%$ rock fragments, $17.96 \%$ matrix and cement fraction and $3.47 \%$ unfilled voids (see table 1a).MI $\geq 19$ is super-mature, MI ranging between $19-9$ is mature, MI between 9 - 3 is sub-mature, MI between 3 - 1 is immature and $\mathrm{MI} \leq 1$ is extremely immature (Nwajide and Hoque, 1985).

MMI = Mineralogical Maturity Index

Average MMI = Quartz $(\mathrm{Q})=53.98$, Feldspar $(\mathrm{F})=41.28$, Rock Fragments $(\mathrm{RF})=4.73($ see table $1 \mathrm{~b})$.

$\mathrm{MMI}=53.98 / 41.28+4.73=1.17$

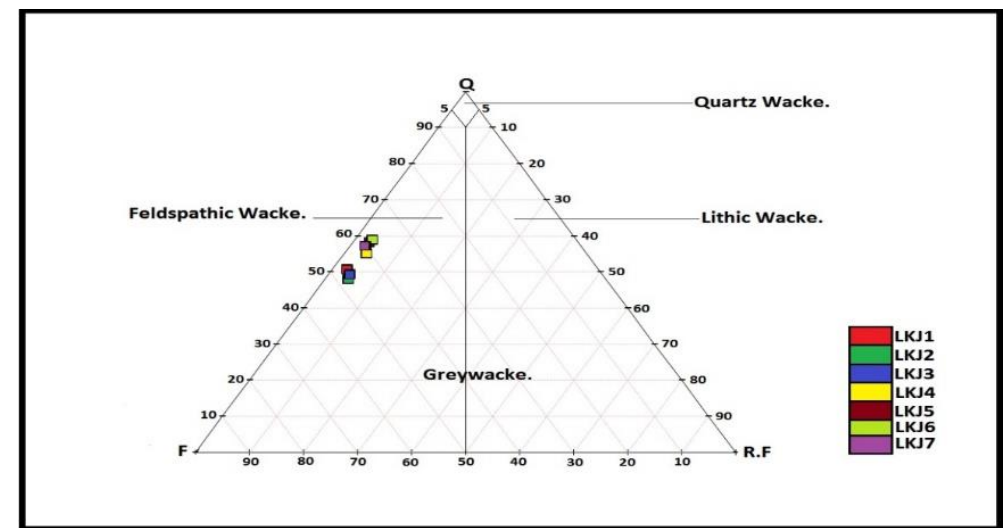

Fig. 9: A). QFRF Ternary Diagram for Sandstone-Mineral Base Classification in Study Area, (After Pettijohn, 1975). 


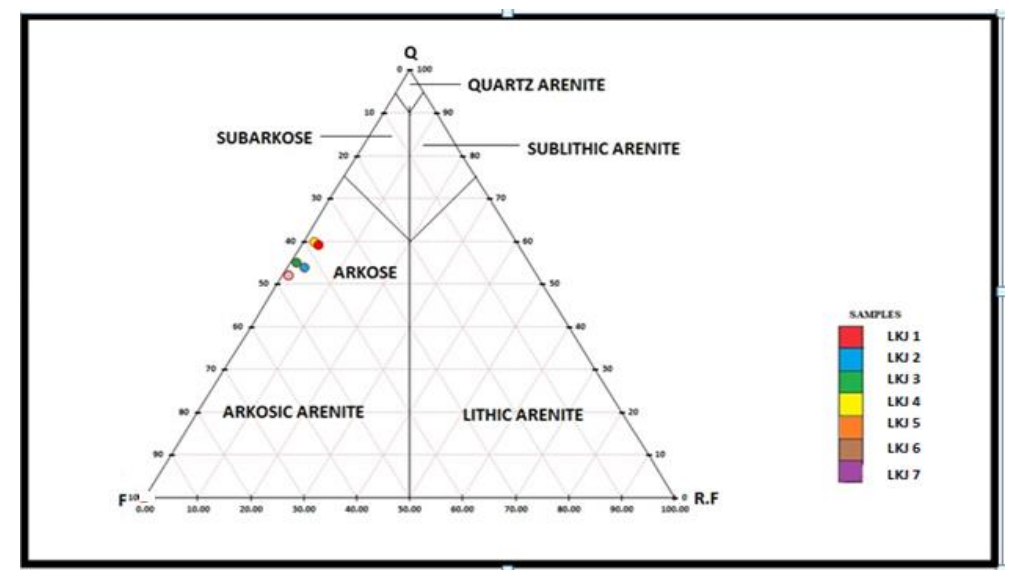

Fig. 9: B). QFRF Ternary Diagram for Sandstone-Mineral Base Classification for Study Area, (After Folk, 1974).

\subsubsection{Heavy mineral analysis}

Results of the heavy mineral suites for Lokoja Sandstones have been presented in table 2 while the photomicrographs are shown in figs. $10 \mathrm{a}-10 \mathrm{e}$. The results reveal zircon, tourmaline, rutile, opaque minerals and non-opaque minerals. The presence of the zircon and tourmaline is indicative of igneous source (e.g. granite, pegmatite, syenite); while the presence of rutile shows metamorphic provenance (e.g. schist or gneiss) (Boggs, 2006). The zircon, tourmaline and rutile (ZTR) index, which is a quantitative definition of these mineral grain assemblages in percentage, is used to infer the provenance rock source (Hubert, 1962). These heavy mineral suites occur as Basement Complex of igneous and metamorphic rocks sediments derivatives (Gideon et al. 2014). The zircon, tourmaline and rutile (ZTR) index calculated from the result of heavy mineral analysis range from $50-83.30 \%$. The calculated average ZTR index (67.99\%) is suggestive of mineralogically immature to submature sediments while the averagely low ZTR index value is indicative of a short distance of transportation from the source area. The heavy mineral grains appear euhedral in shape and are angular to subrounded indicative of a short travel distance and most likely igneous and metamorphic source origin. Stable heavy minerals like zircon and rutile can survive multiple recycling episodes and usually become well rounded thereafter. This commonly implies that the last provenance source was sedimentary (Ikhane et al. 2013). The degree of roundness, therefore, is usually a reflection of the sediment travel distance. ZTR $<75 \%$ imply immature - sub-mature sediments and ZTR $>75 \%$ imply mineralogically matured sediments (Hubert, 1962 cited in Ikhane et al. 2013).

Table 2:Heavy Mineral Composition of Sandstones in the Study Area

\begin{tabular}{|c|c|c|c|c|c|c|c|}
\hline \multirow[b]{2}{*}{$\begin{array}{l}\text { Sample ID/ Min- } \\
\text { eral }\end{array}$} & \multicolumn{6}{|c|}{ Heavy Mineral Composition of Sandstone in the Study area } & \multirow[b]{2}{*}{$\begin{array}{l}\text { ZTR Index } \\
(\%)\end{array}$} \\
\hline & Zircon $\quad$ To & ourmaline & Rutile & Others & $\begin{array}{l}\text { Non } \\
\text { Opaque }\end{array}$ & Opaque & \\
\hline LKJ 1 & 3 & 2 & 1 & 4 & 10 & 14 & 60.00 \\
\hline LKJ 3 & 3 & 1 & 1 & 1 & 6 & 2 & 83.30 \\
\hline LKJ 4 & 3 & - & 1 & 1 & 5 & 5 & 80.00 \\
\hline LKJ 6 & - & 1 & 1 & 2 & 4 & 3 & 50.00 \\
\hline LKJ 7 & 2 & 1 & 1 & 2 & 6 & 7 & 66.67 \\
\hline Avg. & 11 & 5 & 5 & & & & 67.99 \\
\hline $\begin{array}{l}\text { OPTICAL } \\
\text { PROPERTIES }\end{array}$ & $\begin{array}{l}\text { Rounded to sub- } \\
\text { rounded grain, } \\
\text { exhibit high bire- } \\
\text { fringence, blue, } \\
\text { green, pink, yellow } \\
\text { in thin section }\end{array}$ & $\begin{array}{l}\text { Brown colour. } \\
\text { Good pris- } \\
\text { matic cleav- } \\
\text { age }\end{array}$ & $\begin{array}{l}\text { Reddish } \\
\text { brown in thin } \\
\text { section with } \\
\text { prismatic } \\
\text { crystals }\end{array}$ & $\begin{array}{l}\text { Unidentifiable } \\
\text { minerals in thin } \\
\text { section }\end{array}$ & & $\begin{array}{l}\text { Commonly } \\
\text { occur as black } \\
\text { or dark col- } \\
\text { oured grains in } \\
\text { thin section. }\end{array}$ & $\begin{array}{l}\mathrm{Z}+\mathrm{T}+\mathrm{R} \\
\text { Non } \\
\text { Opaque }\end{array}$ \\
\hline
\end{tabular}

ZTR Provenance Ratio: 7:2:17 $\equiv 4: 1: 9$

$\mathrm{Z}=$ ZirconR= RutileT $=$ Tourmaline $\mathrm{O}=$ Opaque Minerals $\mathrm{NO}=$ Non-Opaque

(A)

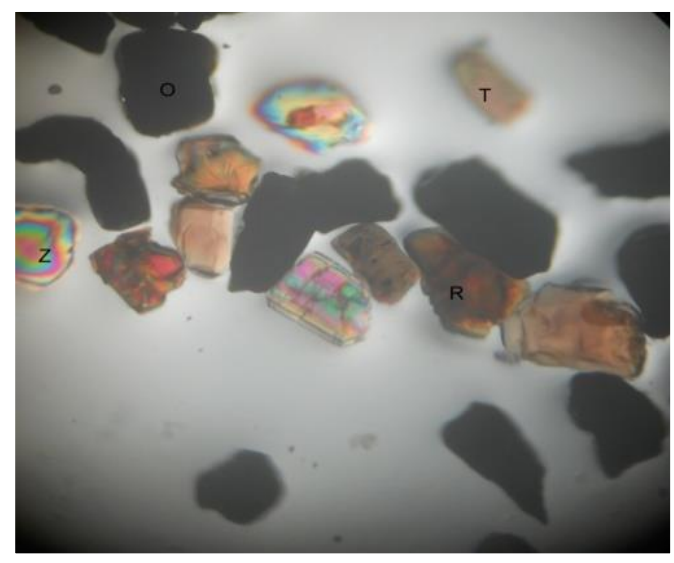

(C)
(B)

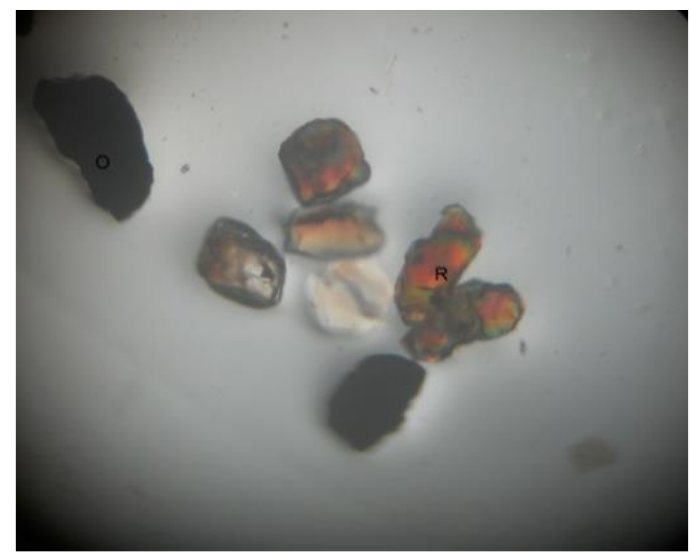

(D) 

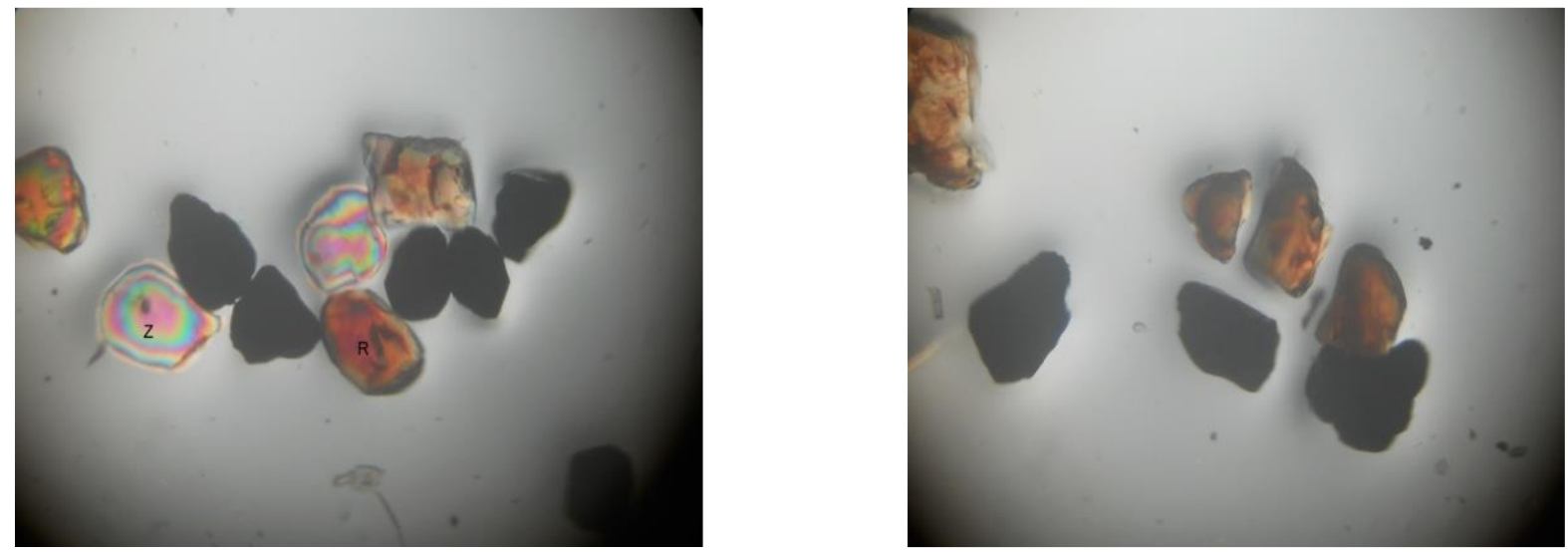

(E)

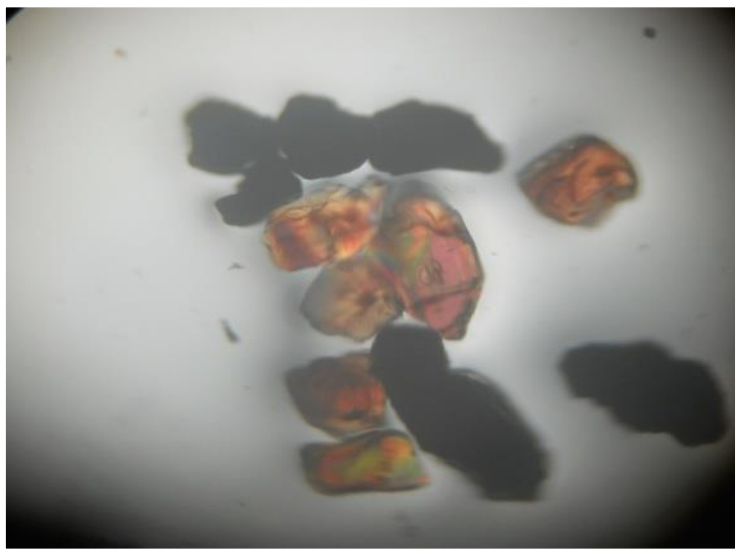

Fig. 10:Photomicrograph of Lokoja Sandstone: [ A- Lokoja 1, B- Lokoja 3, C- Lokoja 4, D- Lokoja 6, E- Lokoja 7.

\subsubsection{X-Ray diffraction (XRD) analysis}

X-ray diffraction (XRD) analysis shows that the mineral assemblage is dominated by quartz and feldspar suggesting a low weathering profile for the Lokoja Sandstones. The feldspars include: orthoclase, microcline and albite, while other associated minerals are muscovite, kaolinite, enstatite and rutile (see fig. 11).

4.2 Major Elements Geochemical Results

The major element concentrations of the sandstones in the study area have been reported as oxide percent by weight in table 3 . These are Silicon (Si), Aluminium ( $\mathrm{Al}$ ), Iron (Fe), Calcium (Ca), Magnesium (Mg), Potassium (K), Sodium (Na), Titanium (Ti), Manganese (Mn) and Phosphorus (P). The elemental compositions of the samples were determined via X-ray Fluorescence (XRF) while the concentration of three major oxide groups - silica, alumina and alkali oxides in conjunction with iron oxides and magnesia were used to classify the sandstones. The results show that the sandstone is enriched in $\mathrm{SiO}_{2}, \mathrm{Al}_{2} \mathrm{O}_{3}, \mathrm{Fe}_{2} \mathrm{O}_{3}, \mathrm{CaO}, \mathrm{MgO}, \mathrm{Na} 2 \mathrm{O}$, and depleted in $\mathrm{MnO}_{2}$ and $\mathrm{P}_{2} \mathrm{O}_{5}$. The potassium oxide $\left(\mathrm{K}_{2} \mathrm{O}\right)$ content - (0.82-0.98) with average value $(0.91)$, is < unity (1) indicating a slightly lower concentration of $\mathrm{K}$ feldspar compared to the plagioclase feldspar. The enrichment of $\mathrm{CaO}$ and $\mathrm{Na}_{2} \mathrm{O}>$ unity (1) in all samples is indicative of Ca-rich and $\mathrm{Na}$-rich plagioclase feldspars possibly derived from basic and felsic igneous or metamorphic rocks. The low value of $\mathrm{K}_{2} \mathrm{O}$ compared to $\mathrm{CaO}$ and $\mathrm{Na}_{2} \mathrm{O}$ may be due to low concentration of the oxide in the source area. The plagioclase is seen to predominate in the thin sections when compared to the orthoclase feldspar. The high values of Silica $\left(\mathrm{SiO}_{2}\right)$ and alumina $\left(\mathrm{Al}_{2} \mathrm{O}_{3}\right)$ is reflected mainly in the large presence of quartz and kaolinite as constituents. The slightly high titanium oxide $\left(\mathrm{TiO}_{2}\right)$ content $(1.10-2.41 \%)$ is suggestive of abundant felsic materials in the source rocks (Condie et al. 1992). Titanium is relatively immobile compared to other elements during various sedimentary processes (Nton, and Adamolekun, 2016).Therefore, its presence in the sandstone in high concentration suggests abundance of the progenitor (source) rock. The high iron $\left(\mathrm{Fe}_{2} \mathrm{O}_{3}\right)$ content may be due to the presence of the heavy minerals observed while the source of magnesium oxide $(\mathrm{MgO})$ may be linked with biotite, a ferromagnesian mineral. It has been widely reported that geochemical signatures of clastic sediments can be utilized in inferring their provenance characteristics (Taylor and Mclennan, 1985; Condie et al. 1992; Cullers, 1995; Armstrong-Altrin et al. 2004; Okunlola and Idowu, 2012).The average major elemental oxides ratios show the relationships of the

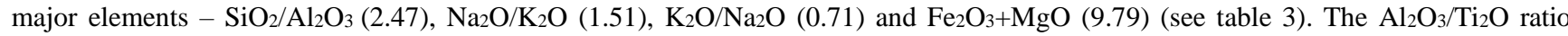
range for the sandstones $\left(9.19\right.$ - 22.36) suggests intermediate to felsic source rocks. Hayashi et al. (1997) pointed out that $\mathrm{Al}_{2} \mathrm{O}_{3} / \mathrm{Ti}_{2} \mathrm{O}$ ratio increases from 3 - 8 for mafic igneous rocks, 8 - 21 for intermediate rocks and $21-70$ for felsic igneous rocks. The comparative values of sodium/potassium alkali ratio $\left(\mathrm{Na}_{2} \mathrm{O} / \mathrm{K}_{2} \mathrm{O}\right)(1.51)$ and that of potassium/sodium alkali ratio $\left(\mathrm{K}_{2} \mathrm{O} / \mathrm{Na}_{2} \mathrm{O}\right)(0.71)$ show the dominance of Na-rich feldspar to the $\mathrm{k}$-feldspar while high value of $\mathrm{Fe}_{2} \mathrm{O}_{3}+\mathrm{MgO}$ indicates contribution from ferromagnesian minerals from a mafic source provenance. 


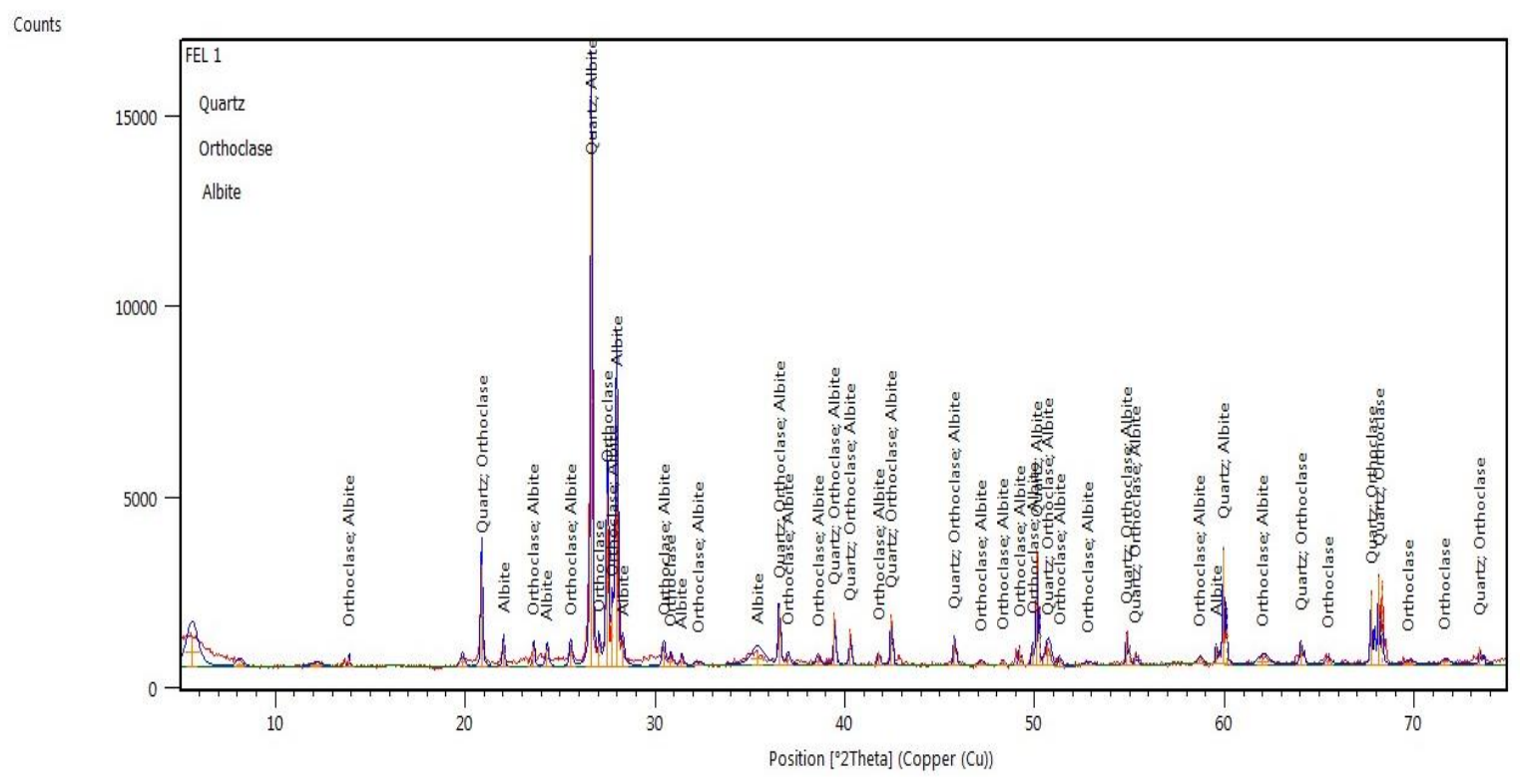

Fig. 11:X-Ray Diffractogram Showing the Sandstone Mineral Spectra.

Table 3:Major Elemental Oxide Composition for the Sandstones in the Study Area (\%)

\begin{tabular}{|c|c|c|c|c|c|c|c|c|c|c|c|}
\hline Sample & $\mathrm{SiO}_{2}$ & $\mathrm{Al}_{2} \mathrm{O}_{3}$ & $\mathrm{Fe}_{2} \mathrm{O}_{3}$ & $\mathrm{CaO}$ & $\mathrm{MgO}$ & $\mathrm{K}_{2} \mathrm{O}$ & $\mathrm{Na}_{2} \mathrm{O}$ & $\mathrm{TiO}_{2}$ & $\mathrm{MnO}_{2}$ & $\mathrm{P}_{2} \mathrm{O}_{5}$ & LOI \\
\hline Lokoja 1 & 57.50 & 24.60 & 7.90 & 4.70 & 1.55 & 0.88 & 1.25 & 1.10 & 0.04 & 0.28 & 0.41 \\
\hline Lokoja 2 & 57.46 & 23.78 & 7.89 & 4.67 & 1.50 & 0.98 & 1.30 & 1.12 & 0.05 & 0.27 & 1.08 \\
\hline Lokoja 3 & 57.60 & 23.68 & 8.78 & 3.86 & 1.78 & 0.97 & 1.32 & 1.44 & 0.02 & 0.35 & 0.69 \\
\hline Lokoja 4 & 56.78 & 23.77 & 8.67 & 3.88 & 1.77 & 0.98 & 1.30 & 1.45 & 0.03 & 0.33 & 1.55 \\
\hline Lokoja 5 & 57.67 & 24.56 & 7.89 & 4.67 & 1.56 & 0.89 & 1.26 & 1.12 & 0.05 & 0.26 & 0.57 \\
\hline Lokoja 6 & 59.36 & 22.06 & 6.63 & 4.27 & 2.47 & 0.82 & 1.52 & 2.40 & 0.02 & 0.43 & 0.22 \\
\hline Lokoja 7 & 58.98 & 22.12 & 6.46 & 4.24 & 2.40 & 0.88 & 1.56 & 2.41 & 0.03 & 0.43 & 0.85 \\
\hline Min. & 56.78 & 22.06 & 6.63 & 3.86 & 1.50 & 0.82 & 1.25 & 1.10 & 0.02 & 0.26 & 0.22 \\
\hline Max. & 59.36 & 24.60 & 8.78 & 4.70 & 2.47 & 0.98 & 1.56 & 2.41 & 0.05 & 0.43 & 1.55 \\
\hline Average & 57.91 & 23.51 & 7.75 & 4.33 & 1.86 & 0.91 & 1.36 & 1.58 & 0.03 & 0.34 & 0.77 \\
\hline
\end{tabular}

Several geochemical diagrams have been used to show the chemical classification of the Lokoja Sandstones, their provenance and tectonic setting. These include those of Pettijohn, et al., (1972), Blatt, et al. (1972), Suttner and Dutta, (1986), Roser and Korsch, (1986. 1988), Lindsey, (1999) and Al-Juboury, (2007). The geochemical classification of the Lokoja Sandstones were investigated using the log ratios of $\mathrm{Na}_{2} \mathrm{O} / \mathrm{K}_{2} \mathrm{O}$ plotted against the log ratios of $\mathrm{SiO}_{2} / \mathrm{Al}_{2} \mathrm{O}_{3}$ (Pettijohn et al. 1972) and the log ratios of $\mathrm{SiO}_{2} / \mathrm{Al}_{2} \mathrm{O}_{3}$ plotted against the log ratios of $\mathrm{K}_{2} \mathrm{O} / \mathrm{Na}_{2} \mathrm{O}$ (Lindsey, 1999) (figs. 12 \& 13).

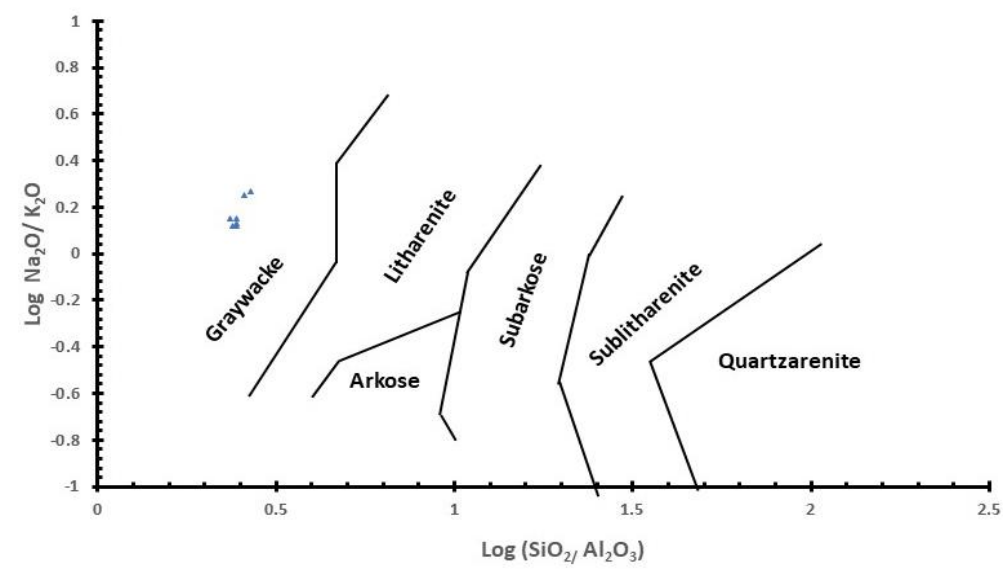

Fig. 12: Chemical Classification of Lokoja Sandstones Based on Log Ratios of $\mathrm{Na}_{2} \mathrm{O} / \mathrm{K}_{2} \mathrm{O}$ Vs. Log Ratios of $\mathrm{Sio}_{2} / \mathrm{Al}_{2} \mathrm{O}_{3}$ of PettijohnEt Al. (1972). 


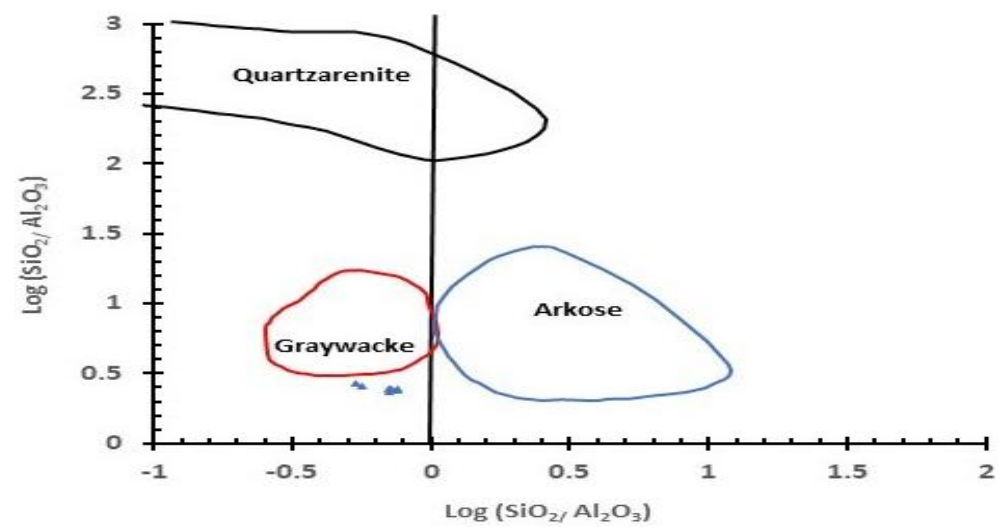

Fig. 13: Compositional Fields for Major Classes of Sandstones Using Log Ratios of $\mathrm{SiO}_{2} / \mathrm{Al}_{2} \mathrm{O}_{3} \mathrm{vs}$. Log Ratios of $\mathrm{K}_{2} \mathrm{O} / \mathrm{Na}_{2} \mathrm{O}$ of $\mathrm{Lindsey}$, (1999).

The $\mathrm{SiO}_{2}$ content and $\mathrm{SiO}_{2} / \mathrm{Al}_{2} \mathrm{O}_{3}$ ratio are the most commonly used geochemical criteria for differentiating mature and immature sediments which also reflect the abundance of quartz, feldspar and clay contents (Potter, 1978). The Lokoja Sandstones plotted as greywacke on the Pettijohn et al., (1972) diagram. Lindsey (1999) modified the diagram of Pettijohn et al. (1972) using the $\log \mathrm{ratio}_{\mathrm{o}}$ of $\mathrm{SiO}_{2} / \mathrm{Al}_{2} \mathrm{O}_{3}$ along the $\mathrm{Y}$-axis instead of $\log \mathrm{Na}_{2} \mathrm{O} / \mathrm{K}_{2} \mathrm{O}$ and this equally plotted the sandstones in the greywacke region. The most peculiar characteristic in the geochemical classification of the sandstones is in their corresponding compositions and all are scattered around the greywacke region. Greywackes are immature sandstones with their matrix value $>15 \%$ of the total sandstone composition (Potter, 1978); thus, the percentage matrix content $>15 \%$ helped in classifying the sandstones as greywacke. The QFL Ternary diagram by Pettijohn, (1975) helped to classify the sandstone as feldsparthic greywacke because of the high feldspar content (fig. 9a). The presence of high feldspar content (potassic and plagioclase), indicate relatively immature sand sediments (Malick and Ishiga, 2016).

Using the classification guide of Lindsey (1999), the sandstone was classified as greywacke. Average value of $\log \mathrm{SiO}_{2} / \mathrm{Al}_{2} \mathrm{O}_{3}$ is 0.39 . This is $<1$ while that of $\log \mathrm{K}_{2} \mathrm{O} / \mathrm{Na}_{2} \mathrm{O}$ is -0.17 which is $<0$ (see table 4). According to Lindsey, (1999) classification guideline: Log $\left(\mathrm{SiO}_{2} / \mathrm{Al}_{2} \mathrm{O}_{3}\right) \geq 1.5$ is for quartz arenites; $\log \left(\mathrm{SiO}_{2} / \mathrm{Al}_{2} \mathrm{O}_{3}\right)<1$ and $\log \left(\mathrm{K}_{2} \mathrm{O} / \mathrm{Na}_{2} \mathrm{O}\right)<0$ is for greywackes. $\log \left(\mathrm{SiO}_{2} / \mathrm{Al}_{2} \mathrm{O}_{3}\right)<1.5$ and $\log \left(\mathrm{K}_{2} \mathrm{O} / \mathrm{Na}_{2} \mathrm{O} \geq 0\right.$ and $\log \left(\mathrm{Fe}_{2} \mathrm{O}_{3}+\mathrm{MgO}\right) /\left(\mathrm{K}_{2} \mathrm{O}+\mathrm{Na} 2 \mathrm{O}\right)<0$ is for arkoses (including sub-arkose); while $\log \left(\mathrm{SiO}_{2} / \mathrm{Al}_{2} \mathrm{O}_{3}\right)<1.5$ and either $\log \left(\mathrm{K}_{2} \mathrm{O} / \mathrm{Na}_{2} \mathrm{O}\right)<0$ or $\log \left(\mathrm{Fe}_{2} \mathrm{O}_{3}+\mathrm{MgO}\right) /\left(\mathrm{K}_{2} \mathrm{O}+\mathrm{Na}_{2} \mathrm{O}\right) \geq 0$ if $\log \left(\mathrm{K}_{2} \mathrm{O} / \mathrm{Na}_{2} \mathrm{O}\right)<0$ is for lithic arenites (sub-greywacke, including protoquartzite). The ternary diagram of Blatt et al. (1972) was further used to confirm the sandstone type. Potassium oxide $\left(\mathrm{K}_{2} \mathrm{O}\right)$ and sodium oxide $\left(\mathrm{Na}_{2} \mathrm{O}\right)$ in conjunction with iron oxide $\left(\mathrm{Fe}_{2} \mathrm{O}_{3}\right)$ and magnesia $(\mathrm{MgO})$ were used to classify the sandstone as sodic sandstones rich in plagioclase feldspars (fig. 14). The calculated ratios of sandstone oxides and logs for chemical classification as well as the recalculated oxides for the chemical classification of the Lokoja Sandstone have been shown in tables 4 \& 5 .

Table 4: Calculated Ratios of Sandstones Oxides and Logs for Chemical Classification from the Study Area

\begin{tabular}{|c|c|c|c|c|c|c|c|c|c|c|c|c|c|}
\hline Sample & $\begin{array}{l}\mathrm{SiO}_{2} / \\
\mathrm{Al}_{2} \mathrm{O}_{3}\end{array}$ & $\begin{array}{l}\mathrm{TiO}_{2} / \\
\mathrm{Al}_{2} \mathrm{O}_{3}\end{array}$ & $\begin{array}{l}\mathrm{Al}_{2} \mathrm{O}_{3} / \\
\mathrm{TiO}_{2}\end{array}$ & $\begin{array}{l}\mathrm{K}_{2} \mathrm{O} / \\
\mathrm{Na}_{2} \mathrm{O}\end{array}$ & $\begin{array}{l}\mathrm{Na}_{2} \mathrm{O} / \\
\mathrm{K}_{2} \mathrm{O}\end{array}$ & $\begin{array}{l}\mathrm{Fe}_{2} \mathrm{O}_{3} \\
/ \mathrm{K}_{2} \mathrm{O}\end{array}$ & $\begin{array}{l}\mathrm{Fe}_{2} \mathrm{O}_{3} \\
+ \\
\mathrm{MgO}\end{array}$ & $\begin{array}{l}\mathrm{Na}_{2} \mathrm{O} \\
+\mathrm{K}_{2} \mathrm{O}\end{array}$ & $\begin{array}{l}\left(\mathrm{Fe}_{2} \mathrm{O}_{3}+\right. \\
\mathrm{MgO}) / \\
\mathrm{Na}_{2} \mathrm{O}+ \\
\mathrm{K}_{2} \mathrm{O}\end{array}$ & $\begin{array}{l}\left(\mathrm{Fe}_{2} \mathrm{O}_{3}+\right. \\
\mathrm{MgO}) / \\
\mathrm{Na}_{2} \mathrm{O}\end{array}$ & $\begin{array}{l}\mathrm{Log} \\
\left(\mathrm{SiO}_{2 /}\right. \\
\left.\mathrm{Al}_{2} \mathrm{O}_{3}\right)\end{array}$ & $\begin{array}{l}\mathrm{Log} \\
\left(\mathrm{K}_{2} \mathrm{O} /\right. \\
\left.\mathrm{Na}_{2} \mathrm{O}\right)\end{array}$ & $\begin{array}{l}\mathrm{Log} \\
\left(\mathrm{Fe}_{2} \mathrm{O}_{3}+\right. \\
\mathrm{MgO}) / \\
\mathrm{Na}_{2} \mathrm{O}+ \\
\mathrm{K}_{2} \mathrm{O}\end{array}$ \\
\hline LKJ 1 & 2.34 & 0.05 & 22.36 & 0.70 & 1.42 & 8.98 & 9.45 & 2.13 & 4.44 & 7.56 & 0.37 & -0.15 & 0.65 \\
\hline LKJ 2 & 2.38 & 0.05 & 22.56 & 0.75 & 1.33 & 8.05 & 9.98 & 2.28 & 4.38 & 7.68 & 0.38 & -0.12 & 0.64 \\
\hline LKJ 3 & 2.43 & 0.06 & 16.44 & 0.73 & 1.36 & 9.05 & 10.56 & 2.29 & 4.61 & 8.00 & 0.39 & -0.14 & 0.66 \\
\hline LKJ 4 & 2.47 & 0.08 & 17.98 & 0.75 & 1.33 & 8.85 & 10.44 & 2.28 & 4.58 & 8.03 & 0.39 & -0.12 & 0.66 \\
\hline LKJ 6 & 2.69 & 0.11 & 9.19 & 0.54 & 1.85 & 8.09 & 9.10 & 2.34 & 3.89 & 5.99 & 0.43 & -0.27 & 0.59 \\
\hline LKJ 7 & 2.56 & 0.14 & 10.01 & 0.56 & 1.77 & 7.34 & 9.14 & 2.44 & 3.75 & 5.86 & 0.41 & -0.25 & 0.57 \\
\hline Min. & 2.34 & 0.05 & 9.19 & 0.54 & 1.33 & 7.34 & 9.10 & 2.13 & 3.75 & 5.86 & 0.37 & -0.27 & 0.57 \\
\hline Max. & 2.69 & 0.14 & 22.36 & 0.75 & 1.85 & 9.05 & 10.56 & 2.44 & 4.59 & 8.03 & 0.43 & -0.12 & 0.66 \\
\hline Avg. & 2.47 & 0.20 & 16.44 & 0.71 & 1.50 & 8.46 & 9.79 & 2.27 & 4.32 & 7.28 & 0.39 & -0.17 & 0.63 \\
\hline
\end{tabular}

Table 5: Recalculated Oxides (\%) for Chemical Classification of the Lokoja Sandstone

\begin{tabular}{lccc} 
& Table 5: Recalculated Oxides $(\%)$ for Chemical Classification of the Lokoja Sandstone \\
\hline Sample No & $\mathrm{Fe}_{2} \mathrm{O}_{3}+\mathrm{MgO}(\%)$ & $\mathrm{Na}_{2} \mathrm{O}(\%)$ & 10.79 \\
$\mathrm{~K}_{2} \mathrm{O}(\%)$ & 10.61 & 7.60 \\
LKJ 1 & 81.61 & 10.27 & 7.99 \\
LKJ 2 & 81.40 & 10.22 & 7.55 \\
LKJ 3 & 82.18 & 10.48 & 7.70 \\
LKJ 4 & 82.08 & 13.29 & 7.17 \\
LKJ 5 & 82.11 & 13.47 & 7.60 \\
LKJ 6 & 79.54 & & \\
LKJ 7 & 78.93 & & \\
\hline
\end{tabular}




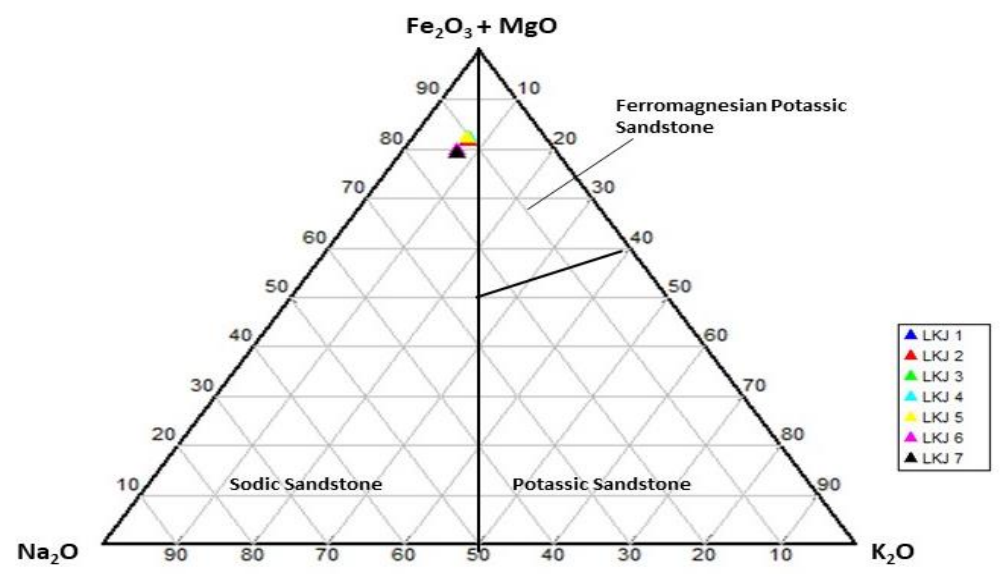

Fig. 14:Ternary Plot for the Lokoja Sandstone (After Blatt Et Al.1972).

For provenance interpretation, $\mathrm{SiO}_{2}$ was plotted against $\mathrm{K}_{2} \mathrm{O} / \mathrm{Na}_{2} \mathrm{O}$ in Roser and Korsch (1986) diagram while the discriminant function diagram of Roser and Korsch (1988) was plotted using major elemental oxides as variables $-\left[\mathrm{Al}_{2} \mathrm{O}_{3}, \mathrm{TiO}_{2}, \mathrm{Fe}_{2} \mathrm{O}_{3}, \mathrm{MgO}_{2} \mathrm{CaO}, \mathrm{Na}_{2} \mathrm{O}\right.$, and $\mathrm{K}_{2} \mathrm{O}$ ] (figs. 15 \& 16).

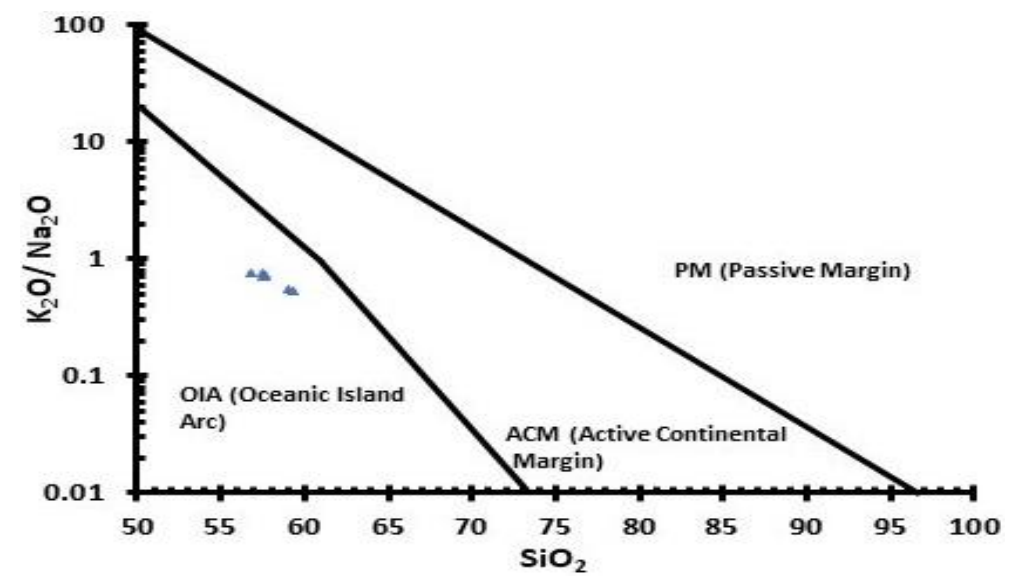

Fig. 15: Tectonic Discrimination Plot for the Lokoja Sandstone (After Roserand Korsch, 1986).

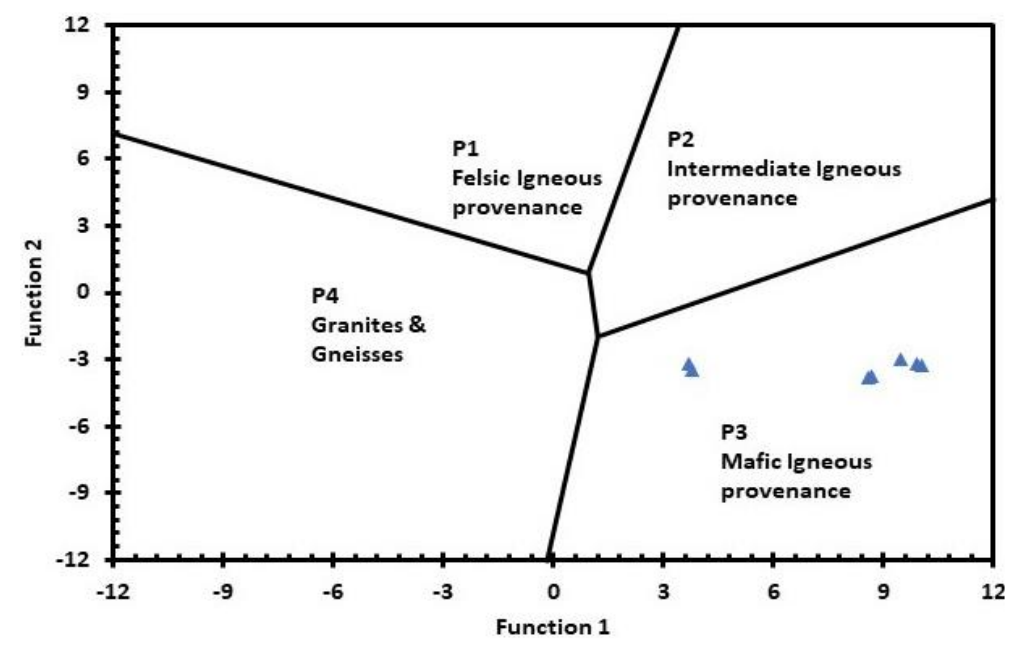

Fig. 16: Tectonic Discrimination Plot for the Lokoja Sandstone (After Roserand Korsch, 1988).

Computed parameters for Discriminant Functions 1 (DF1) and 2 (DF2), for the Lokoja Sandstone; have been presented in tables 6 \& 7. The computed parameters for the discriminant plots were designed to discriminate among four sedimentary provenances. These are the mafic igneous provenance (oceanic island arc); intermediate igneous provenance (mature island arc); felsic igneous provenance (active continental margin); and the recycled granitic-gneissic (sedimentary source). The result shows that the Lokoja Sandstone was deposited in oceanic island arc provenance field while in the discrimination diagram; it plotted the sandstones in the mafic igneous provenance. The ratio of $\mathrm{K}_{2} \mathrm{O} / \mathrm{Na}_{2} \mathrm{O}$ versus $\mathrm{SiO}_{2}$ is generally used for distinguishing between sediments deposited in the passive continental margin and oceanic island arc margin (Roser\&Korsch, 1986). The QFRF chart for tectonic provenance by Dickinson (1985) plots most of the samples in a basement uplifted tectonic setting and a few in a slightly transitional continental setting (fig. 17). 


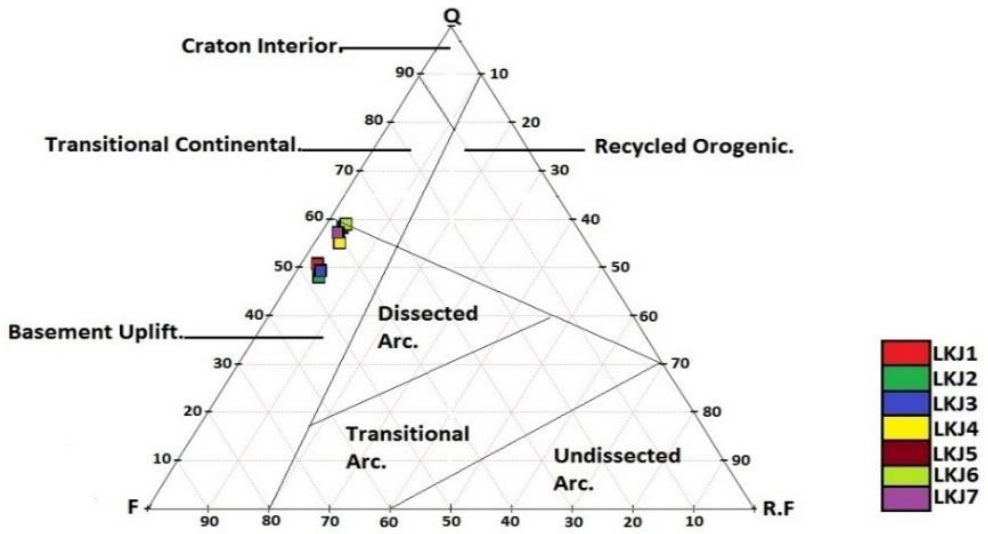

Fig. 17: QFRF Ternary Diagram for Sandstone in the Study Area (After Dickinson, 1985).

Table 6:Computed Parameters for Discriminant Function 1 (DF1) for Lokoja Sandstone

\begin{tabular}{|c|c|c|c|c|c|c|c|c|c|}
\hline Sample & $-1.773 \mathrm{TiO}_{2}$ & $0.607 \mathrm{Al}_{2} \mathrm{O}_{3}$ & $0.76 \mathrm{Fe}_{2} \mathrm{O}_{3}$ & $-1.5 \mathrm{MgO}$ & $0.616 \mathrm{CaO}$ & $0.509 \mathrm{Na}_{2} \mathrm{O}$ & $-1.224 \mathrm{~K}_{2} \mathrm{O}$ & -9.09 & F1 \\
\hline LKJ 1 & -1.95 & 14.93 & 6.00 & -2.33 & 2.90 & 0.64 & -1.08 & -9.09 & 10.02 \\
\hline LKJ 2 & -1.98 & 14.43 & 6.00 & -2.25 & 2.88 & 0.66 & -1.20 & -9.09 & 9.45 \\
\hline LKJ 3 & -2.55 & 14.37 & 6.67 & -2.67 & 2.38 & 0.67 & -1.19 & -9.09 & 8.59 \\
\hline LKJ 5 & -1.99 & 14.91 & 6.00 & -2.34 & 2.88 & 0.64 & -1.09 & -9.09 & 9.92 \\
\hline LKJ 6 & 4.25 & 13.39 & 5.04 & -3.71 & 2.63 & 0.77 & -1.00 & -9.09 & 3.78 \\
\hline LKJ 7 & 4.27 & 13.43 & 4.91 & -3.60 & 2.61 & 0.79 & -1.08 & -9.09 & 3.67 \\
\hline
\end{tabular}

Table 7: Computed Parameters for Discriminant Function 2 (DF2) for Lokoja Sandstone

\begin{tabular}{|c|c|c|c|c|c|c|c|c|c|}
\hline Sample & $-0.445 \mathrm{TiO}_{2}$ & $0.07 \mathrm{Al}_{2} \mathrm{O}_{3}$ & $-0.25 \mathrm{Fe}_{2} \mathrm{O}_{3}$ & $-1.142 \mathrm{MgO}$ & $0.438 \mathrm{CaO}$ & $1.475 \mathrm{Na}_{2} \mathrm{O}$ & $1.426 \mathrm{~K}_{2} \mathrm{O}$ & -6.861 & F2 \\
\hline LKJ 1 & 0.49 & 1.72 & -1.98 & -1.77 & 2.06 & 1.84 & 1.25 & -6.861 & -3.25 \\
\hline LKJ 2 & 0.50 & 1.66 & -1.97 & -1.71 & 2.05 & 1.92 & 1.40 & -6.861 & -3.01 \\
\hline LKJ 3 & 0.64 & 1.66 & -2.20 & -2.03 & 1.69 & 1.93 & 1.38 & -6.861 & -3.79 \\
\hline LKJ 5 & 0.50 & 1.72 & -1.97 & -1.78 & 2.05 & 1.86 & 1.27 & -6.861 & -3.21 \\
\hline LKJ 6 & 1.07 & 1.54 & -1.66 & -2.82 & 1.87 & 2.24 & .17 & -6.861 & -3.45 \\
\hline LKJ 7 & 1.07 & 1.55 & -1.62 & -2.74 & 1.86 & 2.30 & 1.25 & -6.861 & -3.19 \\
\hline
\end{tabular}

\subsection{Trace elements geochemical results}

Results for the geochemical analysis of trace element for the Lokoja Sandstones have been presented in tables $8 \& 9$. Eighteen trace elements were identified and their concentrations given in ppm or $\mathrm{mg} / \mathrm{kg}$. Eighteen trace elements - [Lead $(\mathrm{Pb}), \mathrm{Arsenic}(\mathrm{As}), \mathrm{Cadmium}$ (Cd), Chromium (Cr), Thorium (Th), Copper (Cu), Nickel (Ni), Scandium (Sc), Cobalt (Co), Yttrium (Y), Mercury (Hg), Barium (Ba), Calcium (Ca), Latium (La), Strontium (Sr), Zirconium (Zr), Zinc ( $\mathrm{Zn}$ ) and Phosphorus (P)], was reported as mg/kg (ppm) of trace elements and trace elements ratios. The results show a slight variation from those from the major oxides reported. Trace elements such as $\mathrm{Cr}, \mathrm{Ni}, \mathrm{Co}$, and $\mathrm{V}$ have been used to determine mafic and ultramafic source rocks (Wronkiewicz and Condie, 1987; Huntsman-Mapila et al. 2005). The average concentrations of the following useful designated trace elements in the studied sandstones are: $\mathrm{Cr}, 2.10 \mathrm{ppm}, \mathrm{Co}$, $2.14 \mathrm{ppm}, \mathrm{Sc}, 1.90 \mathrm{ppm}$ as against these other ones of higher values: $\mathrm{Zr}, 126.85 \mathrm{ppm}$; Ba, $178.56 \mathrm{ppm}$ and Sr, $62.67 \mathrm{ppm}$. . The lower concentrations of $\mathrm{Cr}, \mathrm{Co}$, and $\mathrm{Sc}$ and higher concentrations of $\mathrm{Zr}, \mathrm{Ba}$, and $\mathrm{Sr}$, observed in the studied sandstones suggest felsic source rock. Felsic source rocks usually contain lower concentrations of $\mathrm{Cr}, \mathrm{Co}, \mathrm{Ni}$, and $\mathrm{V}$ and higher concentrations of $\mathrm{Ba}, \mathrm{Sr}$, $\mathrm{Y}$, and $\mathrm{Zr}$ than mafic and intermediate source rocks (Wronkiewicz and Condie, 1987; Spallettti, et al. 2008). A significantly high value of Ni, (7.02 $\mathrm{ppm})$ and low value of $\mathrm{Y},(3.23 \mathrm{ppm})$; as well as low concentration of $\mathrm{Cr}$, Co, and Sc suggest very minimal contributions from mafic source rocks. Furthermore, ratios of $\mathrm{Th} / \mathrm{Sc}, \mathrm{La} / \mathrm{Co}, \mathrm{Th} / \mathrm{Co}$ and $\mathrm{Cr} / \mathrm{Th}$ are significantly different in mafic and felsic source rocks and can therefore, provide information about the provenance of sedimentary rocks (Amstrong- Altrin et al. 2004). Although the lower average ratios of $\mathrm{Cr} / \mathrm{Ni}$ (0.32), $\mathrm{Cr} / \mathrm{Th}(0.42), \mathrm{Cr} / \mathrm{Sc}(1.31), \mathrm{Th} / \mathrm{Sc}(2.49)$, and $\mathrm{Th} / \mathrm{Co}$ (2.14), points to felsic source rock for the studied Lokoja Sandstones; values of $\mathrm{La} / \mathrm{Co}$ (7.99), and $\mathrm{Ni} / \mathrm{Co}$ (3.28), however, suggest contributions from mafic source rocks.

\subsection{Weathering indices results}

Weathering indices are useful tools to illustrate weathering profiles and establish the extent of weathering (Cingolani et al. 2003). The degree of chemical weathering is a function of the climate and rates of tectonic uplift (Wronkiewicz \& Condie, 1987), thus chemical weathering intensity suggests a decrease in tectonic activities and or change of the climate towards warm and humid conditions in source regions. Weathering indices of sedimentary rocks can therefore provide useful information of tectonic activity and climatic conditions in the source area. Results of the value ranges for the weathering indices in percent have been presented in table 10 . The chemical Index of Alteration (CIA) (Nesbitt and Young, 1982) and the chemical index of weathering (CIW) (Harnois, 1988) were used to evaluate the intensity of weathering in the provenance area and for paleoclimatic interpretation of the Bida Basin. The Plagioclase Index of Alteration (PIA), can substitute for CIW, as it was used to evaluate the degree of weathering of rocks in the sedimentary basins (Fedo et. al. 1995); (Nadlonek and Bojakowska, 2018); while Mineralogical Index of Alteration (MIA) (Voicu, et. al.1997, 2002); was used to establish a quantitative relationship between intensity of weathering and mobility of elements in the rock during weathering.

Chemical index of alteration (CIA), range from $76.94-79.38$, chemical index of weathering (CIW), from 79.21-82.05, plagioclase index of alteration (PIA), from 78.58 - 81.43 and mineralogical index of alteration (MIA), from 53.63 - 58.76. Low CIA values of approximately $50 \%$ imply an unweathered upper crust or weak weathering, but high values (i.e. $76-100 \%$ ) indicate intense weathering with a com- 
plete removal of alkali and alkaline earth elements and an increase in $\mathrm{Al}_{2} \mathrm{O}_{3}$ (McLennan, 1993, Fedo et al. 1995; Duplus et al. 2006 cited in Madukwe et al. 2014). An intense weathering in a source area is reflected by the removal of mobile or unstable cations of calcium $\left(\mathrm{Ca}^{2+}\right)$, sodium $\left(\mathrm{Na}^{+}\right)$and potassium $\left(\mathrm{K}^{+}\right)$relative to the highly immobile or stable residual constituents of aluminium $\left(\mathrm{Al}^{3+}\right)$ and titanium $\left(\mathrm{Ti}^{2+}\right)$ during weathering (Nesbitt and Young, 1982). Conversely, low CIA values indicate near absence of chemical alteration and consequently may reflect cold and or arid conditions (Nesbitt \& Young, 1982). CIA $=50-60$ indicates an incipient weathering, CIA $=60-80$ an intermediate weathering and CIA > 80 extreme weathering (Nesbitt \& Young, 1982). The average CIA value of $78.04 \%$ is indicative of an intermediate weathering condition (see table 10). Furthermore, the different ranges of MIA values are: incipient $(0-20 \%)$, weak $(20-40 \%)$, moderate $(40-60 \%)$, and intense to extreme $(60-100 \%)$ degree of weathering.

Table 8: Trace Element Concentration (Ppm) for the Lokoja Sandstones

\begin{tabular}{|c|c|c|c|c|c|c|c|c|c|c|c|c|c|c|c|c|c|c|}
\hline $\begin{array}{l}\text { Sam- } \\
\text { ple }\end{array}$ & $\mathrm{Pb}$ & As & $\mathrm{Cd}$ & $\mathrm{Cr}$ & Th & $\mathrm{Cu}$ & $\mathrm{Ni}$ & $\mathrm{Sc}$ & $\mathrm{Co}$ & $\mathrm{Y}$ & $\mathrm{Hg}$ & $\mathrm{Ba}$ & $\mathrm{Ca}$ & $\mathrm{La}$ & $\mathrm{Sr}$ & $\mathrm{Zr}$ & $\mathrm{Zn}$ & $\mathrm{P}$ \\
\hline Lokoja & 1.8 & 1.5 & 1.0 & 2.0 & 5.4 & 5.0 & 8.4 & 1.8 & 2.1 & 3.0 & 1.9 & 201.0 & 30.1 & 17.0 & 67.2 & 143.0 & 15.0 & 38.0 \\
\hline 1 & 8 & 9 & 0 & 2 & 5 & 0 & 0 & 0 & 4 & 0 & 0 & 0 & 0 & 0 & 0 & 0 & 0 & 0 \\
\hline Lokoja & 1.8 & 1.5 & 1.1 & 2.1 & 5.0 & 5.1 & 7.9 & 1.7 & 2.2 & 3.1 & 1.8 & 212.1 & 30.1 & 16.9 & 64.4 & 142.4 & 14.6 & 36.6 \\
\hline 2 & 0 & 5 & 2 & 2 & 5 & 1 & 2 & 7 & 0 & 5 & 7 & 0 & 2 & 5 & 3 & 5 & 7 & 7 \\
\hline Lokoja & 1.8 & 1.5 & 1.2 & 2.0 & 4.3 & 6.0 & 8.6 & 1.5 & 2.4 & 2.0 & 1.2 & 200.0 & 26.6 & 19.1 & 62.0 & 135.2 & 12.0 & 41.0 \\
\hline 3 & 6 & 2 & 0 & 5 & 0 & 0 & 4 & 2 & 2 & 0 & 5 & 0 & 0 & 0 & 0 & 0 & 0 & 0 \\
\hline Lokoja & 1.7 & 1.5 & 1.2 & 2.1 & 4.4 & 5.7 & 7.8 & 1.5 & 2.4 & 2.3 & 1.5 & 212.0 & 26.7 & 18.9 & 61.3 & 135.2 & 12.1 & 40.2 \\
\hline 4 & 8 & 7 & 0 & 6 & 4 & 8 & 9 & 9 & 9 & 3 & 6 & 3 & 2 & 4 & 8 & 2 & 3 & 3 \\
\hline Lokoja & 1.6 & 1.4 & 1.1 & 2.0 & 4.6 & 5.6 & 5.3 & 1.8 & 2.0 & 2.4 & 1.6 & 178.3 & 27.2 & 18.9 & 62.3 & 134.2 & 13.2 & 47.2 \\
\hline 5 & 6 & 8 & 7 & 8 & 4 & 8 & 4 & 8 & 6 & 5 & 7 & 4 & 2 & 4 & 0 & 1 & 4 & 2 \\
\hline Lokoja & 1.6 & 1.4 & 00 & 2.1 & 3.8 & 1.0 & 4.7 & 2.4 & 1.8 & 5.0 & 1.9 & 122.0 & 21.0 & 15.1 & 60.3 & & 11.0 & 61.0 \\
\hline 6 & 2 & 6 & .00 & 5 & 5 & 0 & 0 & 0 & 3 & 0 & 0 & 0 & 0 & 0 & 0 & 8.90 & 0 & 0 \\
\hline Lokoja & 1.7 & 1.4 & 1.1 & 2.1 & 4.3 & 4.3 & 6.2 & 2.3 & 1.8 & 4.6 & 1.8 & 124.4 & 24.6 & 15.3 & 61.0 & 808 & 11.3 & 60.0 \\
\hline 7 & 5 & 9 & 4 & 2 & 1 & 4 & 2 & 7 & 7 & 7 & 7 & 5 & 9 & 5 & 6 & 5.98 & 4 & 3 \\
\hline \multirow{2}{*}{ Min. } & 1.6 & 1.4 & 1.0 & 2.0 & 3.8 & 1.0 & 4.7 & 1.5 & 1.8 & 2.0 & 1.2 & 122.0 & 21.0 & 15.1 & 60.3 & 90 & 11.0 & 38.0 \\
\hline & 2 & 6 & 0 & 2 & 5 & 0 & 0 & 2 & 3 & 0 & 5 & 0 & 0 & 0 & 0 & 3.90 & 0 & 0 \\
\hline \multirow{2}{*}{ Max. } & 1.8 & 1.5 & 1.2 & 2.1 & 5.4 & 6.0 & 8.6 & 2.4 & 2.4 & 5.0 & 1.9 & 201.0 & 30.1 & 19.1 & 67.2 & 143.0 & 15.0 & 61.0 \\
\hline & 8 & 9 & 0 & 5 & 5 & 0 & 4 & 0 & 2 & 0 & 0 & 0 & 0 & 0 & 0 & 0 & 0 & 0 \\
\hline \multirow{2}{*}{ Avg. } & 1.7 & 1.5 & 1.1 & 2.1 & 4.5 & 4.7 & 7.0 & 1.9 & 2.1 & 3.2 & 1.7 & 178.5 & 26.6 & 17.3 & 62.6 & 126.8 & 12.7 & 46.3 \\
\hline & 6 & 2 & 9 & 0 & 8 & 0 & 2 & 0 & 4 & 3 & 2 & 6 & 4 & 5 & 7 & 5 & 7 & 1 \\
\hline
\end{tabular}

Table 9: Trace Element Ratios for the Lokoja Sandstones

\begin{tabular}{|c|c|c|c|c|c|c|c|c|c|c|c|c|c|c|c|c|}
\hline $\begin{array}{l}\text { Rati- } \\
\text { oSample }\end{array}$ & $\mathrm{BSr}$ & $\begin{array}{l}\mathrm{Cr} / \mathrm{Z} \\
\mathrm{r}\end{array}$ & $\mathrm{Zr} / \mathrm{Y}$ & $\begin{array}{l}\mathrm{La} / \mathrm{C} \\
\mathrm{o}\end{array}$ & $\begin{array}{l}\mathrm{Cr} / \mathrm{T} \\
\mathrm{h}\end{array}$ & $\begin{array}{l}\mathrm{Cu} / \mathrm{Z} \\
\mathrm{n}\end{array}$ & $\begin{array}{l}\mathrm{Ni} / \mathrm{C} \\
\mathrm{o}\end{array}$ & $\begin{array}{l}\text { Th/C } \\
\text { o }\end{array}$ & $\begin{array}{l}\mathrm{Th} / \mathrm{C} \\
\mathrm{r}\end{array}$ & $\begin{array}{l}\mathrm{Zr} / \mathrm{S} \\
\mathrm{c}\end{array}$ & $\begin{array}{l}\mathrm{Th} / \mathrm{S} \\
\mathrm{c}\end{array}$ & $\begin{array}{l}\mathrm{Sc} / \mathrm{T} \\
\mathrm{h}\end{array}$ & $\begin{array}{l}\mathrm{Cr} / \mathrm{S} \\
\mathrm{c}\end{array}$ & $\begin{array}{l}\mathrm{Cr} / \mathrm{N} \\
\mathrm{i}\end{array}$ & $\begin{array}{l}\mathrm{La} / \\
\mathrm{Y} \\
\end{array}$ & $\begin{array}{l}\mathrm{La} / \mathrm{T} \\
\mathrm{h}\end{array}$ \\
\hline Lokoja 1 & $\begin{array}{l}2.9 \\
9\end{array}$ & 0.01 & $\begin{array}{l}47.6 \\
7\end{array}$ & 7.94 & 0.37 & 0.33 & 3.93 & 2.55 & 2.70 & $\begin{array}{l}79.4 \\
4\end{array}$ & 3.03 & 0.33 & 1.12 & 0.24 & 5.67 & 3.12 \\
\hline Lokoja 2 & $\begin{array}{l}2.6 \\
7\end{array}$ & 0.03 & $\begin{array}{l}46.4 \\
8\end{array}$ & 7.67 & 0.28 & 0.35 & 3.46 & 2.57 & 2.58 & $\begin{array}{l}78.3 \\
8\end{array}$ & 3.12 & 0.41 & 1.16 & 0.17 & 5.55 & 2.84 \\
\hline Lokoja 3 & $\begin{array}{l}3.2 \\
3\end{array}$ & 0.02 & $\begin{array}{l}67.6 \\
0\end{array}$ & 7.89 & 0.48 & 0.50 & 3.57 & 1.78 & 2.10 & $\begin{array}{l}88.9 \\
5\end{array}$ & 2.83 & 0.35 & 1.35 & 0.24 & 9.55 & 4.44 \\
\hline Lokoja 4 & $\begin{array}{l}3.2 \\
8\end{array}$ & 0.03 & $\begin{array}{l}60.6 \\
8\end{array}$ & 8.12 & 0.44 & 0.48 & 3.47 & 1.97 & 2.13 & $\begin{array}{l}80.3 \\
4\end{array}$ & 2.45 & 0.46 & 1.25 & 0.34 & 8.78 & 3.94 \\
\hline Lokoja 5 & $\begin{array}{l}2.6 \\
3\end{array}$ & 0.02 & $\begin{array}{l}45.5 \\
7\end{array}$ & 7.88 & 0.37 & 0.40 & 2.87 & 1.79 & 2.46 & $\begin{array}{l}89.1 \\
2\end{array}$ & 2.66 & 0.51 & 1.28 & 0.38 & 7.87 & 3.62 \\
\hline Lokoja 6 & $\begin{array}{l}2.0 \\
2\end{array}$ & 0.02 & $\begin{array}{l}19.7 \\
8\end{array}$ & 8.25 & 0.56 & 0.09 & 2.57 & 2.18 & 1.79 & $\begin{array}{l}41.2 \\
1\end{array}$ & 1.60 & 0.62 & 0.90 & 0.46 & 3.02 & 3.92 \\
\hline Lokoja 7 & $\begin{array}{l}2.5 \\
6\end{array}$ & 0.01 & $\begin{array}{l}21.3 \\
4\end{array}$ & 8.16 & 0.47 & 0.16 & 3.10 & 2.12 & 1.90 & $\begin{array}{l}43.2 \\
3\end{array}$ & 1.76 & 0.57 & 2.10 & 0.44 & 4.25 & 3.23 \\
\hline Min. & $\begin{array}{l}2.0 \\
2\end{array}$ & 0.01 & $\begin{array}{l}19.7 \\
8\end{array}$ & 7.67 & 0.28 & 0.09 & 2.57 & 1.78 & 1.79 & $\begin{array}{l}41.2 \\
1\end{array}$ & 1.60 & 0.33 & 0.90 & 0.17 & 3.02 & 2.84 \\
\hline Max. & $\begin{array}{l}3.2 \\
3\end{array}$ & 0.03 & $\begin{array}{l}67.6 \\
0\end{array}$ & 8.25 & 0.56 & 0.50 & 3.93 & 2.57 & 2.70 & $\begin{array}{l}88.9 \\
5\end{array}$ & 3.12 & 0.62 & 2.10 & 0.46 & 9.55 & 4.44 \\
\hline Aver. & $\begin{array}{l}2.7 \\
7\end{array}$ & 0.02 & $\begin{array}{l}44.1 \\
6\end{array}$ & 7.99 & 0.42 & 0.33 & 3.28 & 2.14 & 2.24 & $\begin{array}{l}71.5 \\
2\end{array}$ & 2.49 & 0.46 & 1.31 & 0.32 & 6.38 & 3.59 \\
\hline
\end{tabular}

Table 10: Weathering Indices of Alteration for the Study Area (\%)

\begin{tabular}{|c|c|c|c|c|}
\hline Sample & CIA & CIW & PIA & MIA \\
\hline LKJ 1 & 78.27 & 80.52 & 79.95 & 56.54 \\
\hline LKJ 2 & 76.89 & 81.24 & 79.35 & 56.77 \\
\hline LKJ 3 & 79.38 & 82.05 & 81.43 & 58.76 \\
\hline LKJ 4 & 78.66 & 82.39 & 80.88 & 58.65 \\
\hline LKJ 5 & 77.56 & 80.12 & 80.01 & 54.66 \\
\hline LKJ 6 & 76.94 & 79.21 & 78.58 & 53.88 \\
\hline LKJ 7 & 78.58 & 80.02 & 78.90 & 53.63 \\
\hline Min. & 76.94 & 79.21 & 78.58 & 53.63 \\
\hline Aver. & 78.04 & 80.79 & 79.87 & 56.13 \\
\hline
\end{tabular}

The value of $100 \%$ means complete weathering of a primary material into its equivalent weathered product (Voicu and Bardoux, 2002). An average MIA value of $56.13 \%$ is suggestive of a moderate degree of weathering (see table 10). The CIA and MIA values of the sandstones of the Lokoja Formation suggest that the source area underwent intense recycling with a moderate or intermediate degree of chemical weathering.

The bivariate plot of $\mathrm{SiO}_{2}$ (quartz content) against $\mathrm{Al}_{2} \mathrm{O}_{3}+\mathrm{K}_{2} \mathrm{O}+\mathrm{Na}_{2} \mathrm{O}$ (feldspar content) representing chemical maturity trend as a function of climate proposed by Suttner and Dutta (1986); is shown in fig. 18. The plotted samples show an arid climatic condition in the area tending towards increasing chemical maturity. This shows the low amount of chemical weathering experienced and the level of ma- 
turity of the quartz and feldspars in the sandstones. The bivariate plot of the quartz-matrix ratio $\mathrm{SiO}_{2} / \mathrm{Al}_{2} \mathrm{O}_{3}$ against the mineralogical maturity index (MMI) by Al-Juboury, (2007) (fig. 19); also show the immaturity of the samples. Mineralogical maturity index (MMI) is given as Qtz/(Fsp + Lf), that is (total quartz)/(feldspar + lithic fragments).

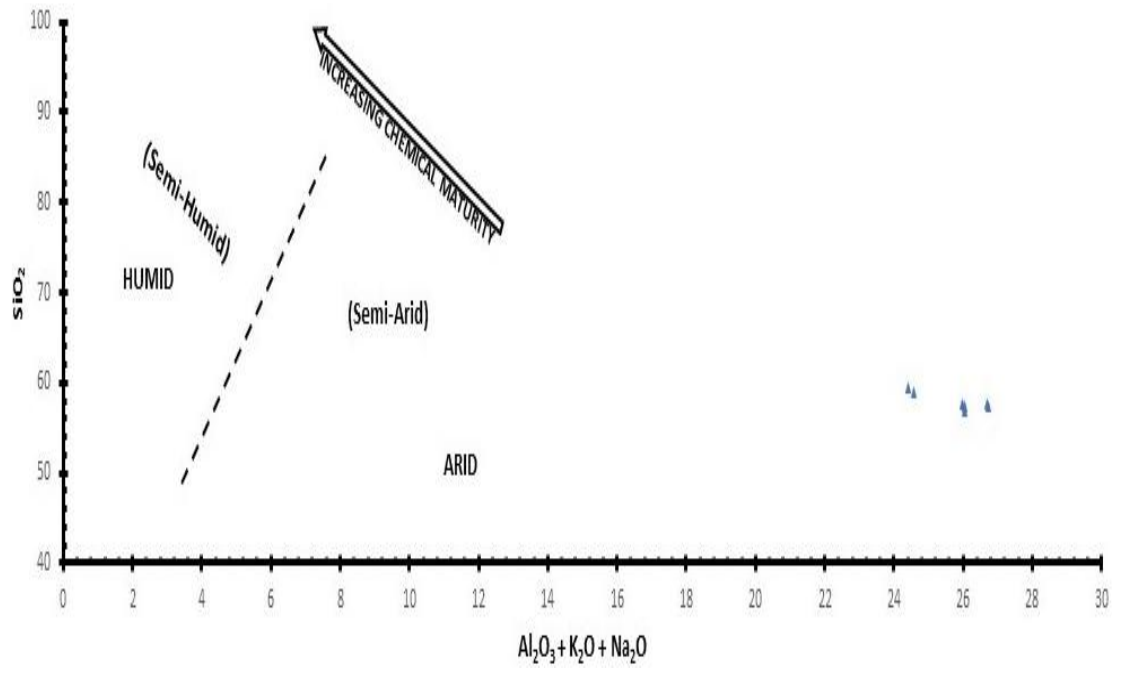

Fig. 18: Bivariate Plot for Chemical Maturity of the Lokoja Sandstone (After Suttner and Dutta, 1986).

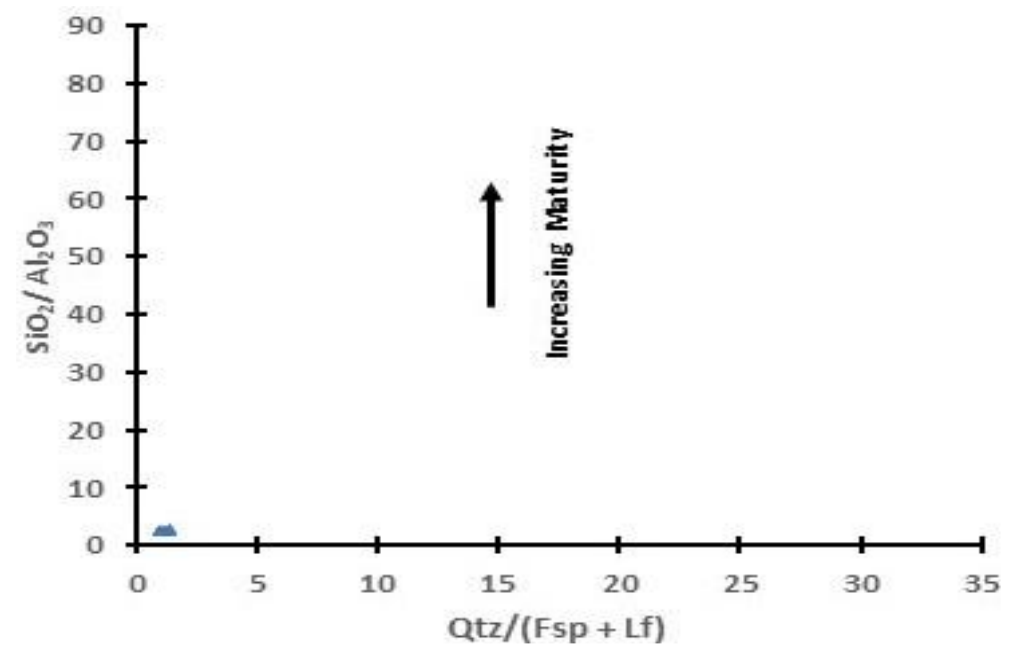

Fig. 19: Bivariate Plot for Chemical Maturity of the Lokoja Sandstone (After Al-Juboury, 2007).

\section{Discussion}

The essence of the petrography and inorganic geochemical studies of the Lokoja Sandstones was to identify and interpret their provenance, source area weathering as well as their paleoclimatic and tectonic setting. Provenance studies are key elements of any basin analysis as they provide basic information regarding their tectonic origin (Miall, 2000; Sanni et al. 2016).Petrography, on the other hand, provide useful clues on how to identify the progenitor source rocks of sandstones with the detrital feldspars acting as key indicators to their paleoclimatic conditions (Folk, 1974; Igwe et al., 2013).

\subsection{Provenance evaluation}

Provenance types and derivatives of sandstone suites have been classified into three - continental block, magmatic arc and recycled orogen based on framework composition of sandstones. Dickinson and Suczek (1979) and Dickinson et al. (1983) also used the QFRF ternary diagrams to discriminate tectonic provenance of sandstone. The abundance of monocrystalline quartz, zircon and tourmaline suggest plutonic rather than supracrustal parentages (Folk, 1974). However, the predominance of rutile over zircon and tourmaline suggests substantial contribution of mineral detritus from metamorphic rocks such as schist or gneiss (Boggs, 2016). Stable heavy minerals like zircon, rutile and tourmaline can indicate maturity of the sandstones.ZTR Index less than $75 \%$ imply immature - sub-mature sandstones while ZTR Index greater than $75 \%$ imply mineralogically matured sandstones (Hubert, 1962; Ikhane et al., 2013). The zircon, tourmaline and rutile (ZTR) index calculated from the result of heavy mineral analysis range from $50-83.30 \%$. The calculated average ZTR index $(67.99 \%)$ is suggestive of mineralogically immature to submature sediments while the averagely low ZTR index value is indicative of a short distance of transportation from the source area. Two lines of interpretation, (textural and mineralogical maturity), have been used to describe the composition of the Lokoja Sandstones. Textural maturity was evaluated on the basis of Folk, (1974) and PettiJohn, (1975) textural maturity flow charts. The mineralogical maturity was deduced using the mineralogical maturity index (MMI) of 
Nwajide and Hoque, (1985). The average mineralogical maturity index (MMI) values of1.17 is $<3.0$ but $>1.0$ while the average matrix and cement content of $17.96 \%$, which is $>15 \%$, have been interpreted as both texturally and mineralogically immature.

Akinyemi, et al., (2014) used Blatt, et al., (1972) scheme to classify the Lokoja Sandstones as lithic arenites (including sub-greywacke and protoquartzites) but Sanni et al., (2016) classified them as arkose to subarkose. Bassey and Eminue (2013) had earlier reported higher percentage of sodic plagioclase and cement in the sandstones but this has not being considered by any worker in their classification. The low ratio of $\mathrm{SiO}_{2} / \mathrm{Al}_{2} \mathrm{O}_{3}$ observed by Odundun and Ogundoro (2019) was attributed to the high degree of clay content suggesting mineralogical immaturity of the sandstones. The percentage matrix and cement content of the Lokoja Sandstones $>15 \%$ has been used to classify the Lokoja Sandstones as greywackes. Plots on the classification diagrams of Pettijohn et al. (1972) and Lindsey (1999) confirmed the sandstones as greywackes. On the basis of Folk (1974) classification scheme, which completely discards matrix as an important element in sandstone classification; the Lokoja Sandstone is classified as a feldspathic arenite, arkosic arenite or simply arkose. However, using the Pettijohn (1975) classification scheme, the sandstones were classified as feldspathic greywackes or simply feldsparthicwackes. Blatt et al. (1972) ternary diagram further described the sandstone as sodic sandstones rich in plagioclase feldspars. The QFRF chart for tectonic provenance after Dickinson (1985) plotted more of the sandstones in a basement uplifted tectonic setting with only a few in the transitional continental setting. Large quantities of alkalis like $\mathrm{Na}_{2} \mathrm{O}$ and $\mathrm{K}_{2} \mathrm{O}$ are said to characterize immature sandstones such as arkoses and greywackes (Madukwe, et al. 2014).

It has been widely reported that geochemical signatures of clastic sediments can further be utilized in inferring their provenance characteristics (Taylor and Mclennan, 1985; Condie et al. 1992; Cullers, 1995; Armstrong-Altrin et al.2004). Results of major elements and oxides in this work, strongly suggests intermediate to felsic source rocks (table 4.21); while comparative values of sodium/potassium alkali ratio $\left(\mathrm{Na}_{2} \mathrm{O} / \mathrm{K}_{2} \mathrm{O}\right)(1.51)$ and that of potassium/sodium alkali ratio $\left(\mathrm{K}_{2} \mathrm{O} / \mathrm{Na} 2 \mathrm{O}\right)(0.71)$ show the dominance of Na-rich feldspar to the k-feldspar. The high value of $\mathrm{Fe}_{2} \mathrm{O}_{3}+\mathrm{MgO}$ shows contribution from ferromagnesian minerals of mafic source provenance. The discrimination diagrams of Roser\&Korsch, $(1986 ; 1988)$ also plotted the sandstones in the mafic igneous provenance and oceanic island arc regions (see figs. $4.27 \& 4.28)$. However, the low average concentrations of $\mathrm{Cr}(2.10 \mathrm{ppm})$, Co (2.14 ppm), and Sc (1.90 ppm) as against those of higher values like $\mathrm{Zr}(126.85 \mathrm{ppm}), \mathrm{Ba}(178.56 \mathrm{ppm})$ and $\mathrm{Sr}(62.67 \mathrm{ppm})$, observed in the studied sandstones suggests felsic source provenance (see table 4.23). The lower average ratios for $\mathrm{La} / \mathrm{Co}, \mathrm{Th} / \mathrm{Co}, \mathrm{Th} / \mathrm{Sc}, \mathrm{Ni} / \mathrm{Co}, \mathrm{Cr} / \mathrm{Ni}, \mathrm{Cr} / \mathrm{Sc}$, and $\mathrm{Cr} / \mathrm{Th}$ also suggest felsic source rocks for the studied sandstones. These results are similar to the discriminant function plot by Madukwe et al. (2014) that showed sandstones derived from felsic igneous source while the ratios of $\mathrm{Ni} / \mathrm{Co}, \mathrm{Cr} / \mathrm{Ni}, \mathrm{Cr} / \mathrm{Th}, \mathrm{Cr} / \mathrm{Sc}, \mathrm{Th} / \mathrm{Sc}, \mathrm{La} / \mathrm{Co}$ and $\mathrm{Th} / \mathrm{Co}$ also suggests a felsic source rock. Significantly high values of $\mathrm{Ni}(7.02 \mathrm{ppm}), \mathrm{La} / \mathrm{Co}$ (7.99), and Ni/Co (3.28) as well as the low concentration value of $\mathrm{Y},(3.23 \mathrm{ppm}$ ) suggests contributions from mafic source rocks (table 4.13). It is seen here that the Lokoja Sandstones have both felsic and mafic provenance sources.

\subsection{Source area weathering}

Weathering indices are useful tools to the extent of weathering. For this work, results of the weathering indices $(\%)$ have been presented in table 6; chemical index of alteration (CIA) - (76.94-79.38), chemical index of weathering (CIW) - (79.21-82.05), plagioclase index of alteration (PIA) - (78.58-81.43), and mineralogical index of alteration (MIA) - (53.63-58.76).An average CIA value of 78.04\% is indicative of an intense weathering in the source area while an average MIA value of $56.13 \%$ is suggestive of a moderate degree of weathering (table 6).MIA values range from incipient (0-20\%), weak (20-40\%), moderate (40-60\%), and intense to extreme (60-100\%) degree of weathering. $100 \%$ value means complete weathering of a primary material into its equivalent weathered product (Voicu and Bardoux, 2002). The CIA and MIA values of the Lokoja Sandstones indicate a source area that underwent intense recycling but moderate degree of chemical weathering.

\subsection{Paleoclimatic and tectonic setting}

A key indicator of paleoclimate for sandstones is its detrital feldspar content (Folk, 1974; Igwe et al. 2013). Dickinson et al. (1985) compositional framework for sandstones i.e. the Q, F, \& RF ternary diagram, was used to interpret the source area climatic conditions as well as progenitor rock types. This diagram plotted the Lokoja Sandstone on a basement uplift tectonic setting. The high percentage of feldspars seen from the photomicrographs supports a dry climatic condition for this tectonic setting. Highly chemically weathered and depleted feldspars would have represented a humid climatic condition irrespective of the closeness to the depositional basin. Suttner and Dutta (1986) diagram also helped to infer the climatic conditions in the source area.

The tectonics responsible for the genesis of the Bida Basin has been interpreted to be closely connected with the Santonian orogenic movements of south-eastern Nigeria in the Benue Trough (Adeleye, 1975; Kogbe, 1989). Sandstones in south-eastern Nigeria, of Albian - Santonian times, are feldspathic and belong to the first order sedimentary cycle while those of Campanian - Eocene times, are essentially quartz arenites and belong to the second order sedimentary cycle (Hoque, 1977). Akinyemi, et al. (2014) classified the Lokoja Sandstones as lithic arenites from a second order sedimentary cycle while Sanni et al. (2016) classified them as arkose to subarkose from a first order sedimentary cycle. A larger sample population will certainly show this dispersion and variability of the sediment sources. The high clay matrix and feldspar content observed were, however, used to classify the sandstones as feldspathic greywackes. The contained rip-up clast within the sandstones shows the moderate weathering of the underlying basement rocks and reworking of autochthonous materials during a first order cycle of deposition.

\section{Conclusion}

Petrography was used to infer a plutonic igneous and metamorphic source rock parentage for the Lokoja Sandstone. It also helped to classify it as mineralogically and texturally immature - submature feldspathic/arkosic arenite or feldsparthicwacke. Geochemical signatures were used to infer felsic - intermediate - mafic provenance source rocks with discrimination diagrams plotting them in the mafic igneous provenance and oceanic island arc regions. The tectonics responsible for the genesis of the Bida Basin is interpreted to be closely connected with the Santonian orogenic movements of south-eastern Nigeria that has feldspathic sandstones of the first order sedimentary cycle (Albian - Santonian times ), and quartz arenites of the second order sedimentary cycle (Campanian - Eocene times). The paleoclimatic setting show sandstones more of basement uplifted tectonic setting from an arid climatic condition while weathering indices indicated a source area that underwent a moderate degree of chemical weathering but an intense recycling. 


\section{Acknowledgement}

The authors are grateful to the Department of Earth Sciences, Salem University Lokoja; Department of Geology, Ahmadu Bello University Zaria; The Nigerian Geological Survey Agency (NGSA) Kaduna, and Max-Planck-Institut fur Chemie, Mainz, Rhineland-Palatinate, Germany. The various reviewers, whose comments and suggestions have helped to improve the quality of this paper, are also acknowledged. Thank you all.

\section{References}

[1] Adeleye, D. R., (1974), Sedimentology of the fluvial Bida sandstones (Cretaceous) Nigeria, Sedimentary Geology, 12, 124.https://doi.org/10.1016/0037-0738(74)90013-X

[2] Adeleye, D. R., (1975), Nigerian Late Cretaceous Stratigraphy and Paleogeography. Bull. AAPG. $59 . \quad 2302 \quad-$ 2313.https://doi.org/10.1306/83D92258-16C7-11D7-8645000102C1865D.

[3] Adeleye, D. R., (1989), The Geology of the Middle Niger Basin, In Kogbe, C. A., (Ed.), Geology of Nigeria, 2nd edition, Rock View (Nigeria) Limited Jos, Nigeria, 335-339.

[4] Akande, S. O., Ojo, O. J., Erdtmann , B. D., and Hetenyi, M., (2005), Paleoenvironments, Organic Petrology and Rock-Eval Studies on Source Rock Facies of the Lower Maastrichtian Patti Formation, Southern Bida Basin Nigeria, Journal of African Earth Sciences, 8. 394406.https://doi.org/10.1016/j.jafrearsci.2005.07.006.

[5] Akande, S. O., Ojo, O. J., Adekeye, O. A., and Ladipo, K. O., (2006), A Geological Field Guide to the Southern Bida Basin. Nigerian Association of Petroleum Explorationists (NAPE), 24th Annual Conference and Exhibition, Abuja, $21 \mathrm{p}$

[6] Akinmosin, A., Osinowo, O. O., (2008), Geochemical and Mineralogical Composition of Ishara Sandstone Deposit, SW Nigeria, Cont. J. Earth Sci., 3. 3339

[7] Akinyemi, S. A., Adebayo, O. F., Ojo, A. O., Fadipe, O. A., and Gitari, W. M., (2014), Geochemistry and Mineralogy of the Campanian Sandstone of Lokoja - Bassange Formation,Middle Niger Basin (Lokoja Sub - Basin), Nigeria: Implications for Provenance, Weathering, Tectonic Setting and Paleo - Redox Condition, Journal of Natural Sciences Research. 16. 65-89.

[8] Akpokodje, E.G., Etu-Efeotor, J.O and Olorunfemi, B.N., (1991), The composition and Physical Properties of some Ceramic and Pottery Clays of South Eastern Nigeria, Journal of Mining and Geology, 27, 9 - 15.

[9] Benkhelil, J., (1989), The origin and Evolution of the Cretaceous Benue Trough, Nigeria, Journal of African Earth Sciences. 8. 251282.https://doi.org/10.1016/S0899-5362(89)80028-4.

[10] Blatt, H., Middleton, G. and Murray, R. (1972), Origin of Sedimentary Rocks, Eaglewood Cliffs, New Jersey, Prentice-Hall, 634 p.

[11] Bock, B., McLennan, S. M., and Hanson, G. N., (1998), Geochemistry and Provenance of the Middle Ordovician Austin Glen Member (Normanskill Formation) and the Taconian Orogeny in New England, Journal of Sediment. 45. 635-655.https://doi.org/10.1046/j.1365-3091.1998.00168.x

[12] Boggs, S. J., (2006), Principle of Sedimentology and Stratigraphy, Person Printing Hall Upper Saddle River, New Jersey, 4th Edition. 662p.

[13] Boggs, S. J., (2009), Petrology of Sedimentary Rocks, Cambridge University Press, New York, 2nd Edition, 600p.https://doi.org/10.1017/CBO9780511626487.

[14] Braide, S. P., (1990), Petroleum Geology of the Southern Bida Basin, Nigeria. AAPG Am. Assoc. Pet. Geol.) Bull, 74 (5), 717.https://doi.org/10.1306/44B4ADAC-170A-11D7-8645000102C1865D

[15] Braide, S. P., (1992a), Geological Development, Origin and Energy Mineral Resources Potential of the Lokoja Formation in the Southern Bida Basin, Journal of Mining and Geology. 28. (1).33-44.

[16] Braide, S. P., (1992b), Syntectonic Fluvial Sedimentation in the Central Bida Basin, Journal of Mining and Geology. 28. (1), 55-63.

[17] Braide, S. P., (1992c), Alluvial Fan Depositional Model in the Northern Bida Basin, Journal of Mining and Geology. 28. (1).65-73.

[18] Burke, K., (1972), Longshore Drift, Submarine Canyons, and Fans in Development of Niger Delta, AAPG. Bull. 56. 19751983.https://doi.org/10.1306/819A41A2-16C5-11D7-8645000102C1865D.

[19] Condie, K.C., Boryta, M.D., Liu, J. and Quian, X., (1992), The Origin of Khondalites: Geochemical Evidence from the Archean to Early Proterozoic Granulitic Belt in the North China Craton: Precambrian Research, 59(3-4), 207-223.https://doi.org/10.1016/0301-9268(92)90057-U.

[20] Dickinson, W.R., Beard, L.S.,Brakenridge, G.R. Erjavec, J.L. Ferguson, R.C. Inman, K.F. Knepp, R.A. Lindberg, F.A. and Ryberg, P.T., (1983), "Provenance of North American Phanerozoic sandstones in relation to tectonic setting", Geological Society of America Bulletin, 94, 222235.https://doi.org/10.1130/0016-7606(1983)94<222:PONAPS>2.0.CO;2.

[21] Dickinson, W. R., (1985), Interpreting Provenance relation from Detrital Modes of Sandstones, In: Zufaa, G. G., (ed.), Provenance of Arenites, D. Reidel Publishing Company, NATO ASI Series, C-148, D. Reidel Publishing Company, Dordrecht, 333-363. https://doi.org/10.1007/978-94-0172809-6 15.

[22] Dickinson, W. R., and Suczek, C. A., (1979), Plate Tectonics and Sandstone Composition, AAPG Bulletin. 63. (12). 21642182.https://doi.org/10.1306/2F9188FB-16CE-11D7-8645000102C1865D.

[23] Ehinola, O. A., Sonibare, O. O., Falana, A. M. and Jarvie, D., (2006), Organic Geochemistry and Biomarker Evaluation of Shale Units of the Maastrichtian Patti Formation, Bida Basin Nigeria,Nigerian Association of Petroleum Explorationists (NAPE) Bulletin. 19. (1). 78-88.

[24] Fedo, C.M., Eriksson, K., Krogstad, E. J., (1996). Geochemistry of shale from the Archean ( 3.0 Ga) Buhwa Greenstone belt, Zimbabwe: Implications for provenance and source area weathering: GeochimicaetCosmochimica Acta, 60, 1751-1763.https://doi.org/10.1016/0016-7037(96)00058-0.

[25] Folk, R. L., (1974), Petrology of Sedimentary Rocks, Hemphill Publ. Co., Austin, Texas. 159p.

[26] Gideon, Y. B., Fatoye, F. B., and Omada, J. I., (2014), Sedimentological Characteristics and Geochemistry of Ajali Sandstone exposed at Ofe-Jiji and Environs, Northern Anambra Basin, Nigeria, Research Journal of Environmental and Earth Sciences, 6(1), 1017.https://doi.org/10.19026/rjees.6.5735.

[27] Gluyas, J., and Swarbrick, R., (2004), Petroleum Geoscience, Blackwell Publishing Company USA, 349p.

[28] Habib, M. and Xie, C., (2012), Nigeria's Inland Basins: Investment Opportunities and Environment, Journal of Petroleum and Gas Exploration Research, 2 (11), 202-211.

[29] Hayashi, K., Fujisawa, H., Holland, H., Ohmoto, H., (1997), Geochemistry of 1.9 Ga Sedimentary Rocks from North-eastern Labrador, Canada: GeochimicaetCosmochimica Acta, 61(19), 4115-4137.https://doi.org/10.1016/S0016-7037(97)00214-7.

[30] Hebron, M. M., (1988), Geochemical Classification of Terrigenous Sands and Shales from Core or Log Data. Journal of Sedimentary Petrology, 58: 820-829.https://doi.org/10.1306/212F8E77-2B24-11D7-8648000102C1865D.

[31] Hoque, M., (1977), Petrographic Differentiation of Tectonically Controlled Cretaceous Sedimentary Cycles, Southeastern Nigeria, Sed. Geol. 17, 235-245.https://doi.org/10.1016/0037-0738(77)90047-1.

[32] Hoque, M., and Nwajide, C. S., (1984), Tectono-Sedimentological Evolution of an Elongate Intracratonic Basin (Aulacogen): The Case of the Benue Trough of Nigeria. Nig. J. Min. Geol. 21, 19-26.

[33] Hoque, M., and Nwajide, C. S., (1985), Application ofMarkov Chain and Entropy Analysis to LithologicSuccessions: An example from the Cretaceous of the Benue Trough (Nigeria), Geol. Rndsh. 74, 165 - 177.https://doi.org/10.1007/BF01764578.

[34] Hubert, J. T., (1962), Zircon-Tourmaline-Rutile Maturity Index and Interdependence of the Composition of Heavy Minerals Assemblages with the Gross Composition and Texture of Sandstones, Journal of Sedimentary Petrology. 32: 440-450.https://doi.org/10.1306/74D70CE5-2B21-11D78648000102C1865D. 
[35] ldowu, J.O and Enu, E I. (1992), Petroleum Geochemistry of some Late Cretaceous Shales from the Lokoja Sandstone of Middle Niger Basin, Nigeria, Journal of African Earth Sciences. 14. 443-455.https://doi.org/10.1016/0899-5362(92)90047-G.

[36] Igwe, E. O., Amoke, G. U. and Ngwu, C. N., (2013), Provenance and Tectonic Setting of Amasiri Sandstone (Turonian) in Ugep Area, Southern Benue Trough, Nigeria: Evidences from Petrography and Geochemistry, Global Journal of Science Frontier Research Environment \& Earth Science. 13: (2). 1.0: 32-40.

[37] Ikhane, P. R., Akintola, A. I., Bankole, S. I., Oyebolu, O. O., and Ogunlana, E. O., (2013), Granulometric Analysis and Heavy Mineral Studies of the Sandstone Facies exposed near Igbile, Southwestern Nigeria, International Research Journal of Geology and Mining (IRJGM) (2276-6618), 3 (4), 158-178

[38] Kogbe, C. A., (Ed.) (1989), Geology of Nigeria. 2nd Edition, Rock View (Nigeria) Limited Jos, Nigeria. 538p.

[39] Likasson, O. K., (1993), Application of Trend Surface Analysis to Gravity data over the Middle Niger Basin, Nigeria. Journal of Mining and Geology, 29 (2), 11-19.

[40] Madukwe, H. Y., Akinyemi, S. A., Adebayo, O. F., Ojo, A. O., Aturamu, A. O., and Afolagboye, L. O., (2014), Geochemical and Petrographic Studies of Lokoja Sandstone: Implications on Source Area Weathering, Provenance and Tectonic Setting, International Journal of Scientific \& Technology Research. 3: 12 .

[41] Malick, B. M. L., and Ishiga, H., (2016), Geochemical Classification and Determination of Maturity Source Weathering in Beach Sands of Eastern San' in Coast, Tango Peninsula, and Wakasa Bay, Japan, Earth Science Research; 5 (1): 44-56.https://doi.org/10.5539/esr.v5n1p44.

[42] Mebradu, S., lmhanobe, J. and Kparidei, L. Z., (1986), Palynostratigraphy of the Ahoko sediments from the Nupe Basin, N.W. Nigeria, Review of Paleobotany and Palynology.48: 303-310.https://doi.org/10.1016/0034-6667(86)90064-3.

[43] Milner, H. B., (1962), Sedimentary Petrography, 2nd ed. Vol. 1, Methods in Sedimentary Petrography, Vol. 2, Principles and Application, New York, MacMillan Company, Vol. 1, 643 p. Vol. 2, 75 p.

[44] Mukhtar, H., and Congjiao, X., (2012), Nigeria's Inland Basins: Investment Opportunities and Environment, Journal of Petroleum and Gas Exploration Research. 2 (11): 202-211.

[45] Murat, R. C., (1972), Stratigraphy and paleogeography of the Cretaceous and Lower Tertiary in Southern Nigeria. In: Dessauvagie, T. F.J., and Whiteman, A. J., (Eds.), African Geology, University of Ibadan Press, 251-266.

[46] Nadlonek, W. and Bojakowska, I., (2018), Variability of Chemical Weathering Indices in Modern Sediments of the Vistula and Odra rivers (Poland), Applied Ecology and Environmental Research 16 (3): 2453-2473. https://doi.org/10.15666/aeer/1603 24532473.

[47] Nton, M. E., and Adamolekun, O. J., (2016), Sedimentological and Geochemical Characteristics of Outcrop Sediments of Southern Bida Basin, Central Nigeria: Implications for Provenance, Paleoenvironment and Tectonic History, Ife Journal of Science, 18: 2. 345-369.

[48] Nwajide, C. S., (2013), Geology of Nigeria’s Sedimentary Basins, CSS Press. 565p.

[49] Nwajide, C.S., and Hoque, M., (1985), Problem of Classification and Maturity- Evaluation of diagnostically altered fluvial Sandstone, Geologic on Nujibouw: 64: 67-70.

[50] Nwajide, C. S., and Reijers, T, J. A., (1996), Sequence architecture in outcrops: examples from the Anambra Basin Nigeria, Nigerian Association of Petroleum Explorationists (NAPE) Bulletin. 11: 23-33.

[51] Obaje, N.G., (1994), Coal Petrography, Microfossils and Palaeo-environment of Cretaceous Coal Measures in the Middle Benue Trough of Nigeria, TübingerMikropal. Mitt. 11:1-50.

[52] Obaje, N. G., (2009), Geology and Mineral Resources of Nigeria, Springer, Heidelberg, 221p.https://doi.org/10.1007/978-3-540-92685-6.

[53] Obaje, N. G., Wehner, H., Scheeder, G., Abubakar, M. B., and Jaura, A., (2004), Hydrocarbon prospectivity of Nigeria's inland basins: from the viewpoint of organic geochemistry and organic petrology, American Association of Petroleum Geologists Bulletin (AAPG). 87: 325353.https://doi.org/10.1306/10210303022.

[54] Obaje, N. G., Attah, D. O., Opeloye, S. A., and Moumouni, A. (2006), Geochemical Evaluation of the Hydrocarbon Prospects of Sedimentary Basins in Northern Nigeria, Geochemical Journal. 40: 227-243.https://doi.org/10.2343/geochemj.40.227.

[55] Obaje, N. G., Moumouni, A., Goki, N. G. and Chaanda, M. S., (2011), Stratigraphy, Paleogeography and Hydrocarbon Resource Potentials of the Bida Basin in North-Central Nigeria, Journal of Mining and Geology. 47. (2): 97-113.

[56] Obaje, N. G., Musa, M. K., Odoma, A. N. and Hamza, H., (2011), The Bida Basin in North-Central Nigeria: Sedimentology and Petroleum geology, Journal of Petroleum and Gas Exploration Research. 1. (1): 001-013.

[57] Obaje, N. G., Balogu, D. O., Idris-Nda, A., Goro, I. A., Ibrahim, S. I., Musa, M. K., Dantata, S. H., Yusuf, I., Mamud-Dadi, N., Kolo, I. A.(2013), Preliminary Integrated Hydrocarbon Prospectivity Evaluation of the Bida Basin in North Central Nigeria, Petroleum Technology Development Journal. 3. (2): 36-65.

[58] Obaje, N. G., Abdullahi, I. N., Okoro, A. U., Akpunonu, E. O., Jatau, S. B., Goro, A. I., and Dantata, S. H., (2015), New Assessment for the Central Nigeria's Bida Basin Highlights Geological Prospects, Oil and Gas Journal,

[59] Obiefuna, G. I., and Orazulike, D. M., (2011), Geochemical and Mineralogical Composition of the Bima Sandstone Deposit, Yola Area, NE Nigeria, Research Journal of Environmental and Earth Sciences. 3. (2): 95102.

[60] Ojo, O. J., (1992), Petroleum geology and sedimentology of the Patti Formation, Bida Basin Nigeria, M.Sc. Thesis, University of Ibadan, Ibadan, Nigeria 149p.

[61] Ojo, O. J., (2012), Sedimentary Facies Relationships and Depositional Environments of the Maastrichtian Enagi Formation, Northern Bida Basin, Nigeria, Journal of Geography and Geology. 4. (1): 12p.https://doi.org/10.5539/jgg.v4n1p136.

[62] Ojo, O. J., and Akande, S. O., (2006), Sedimentology and palynological studies of the Patti Formation, southern Bida Basin, Nigeria: Implications for paleoenvironments and paleogeography, Nigeria Association of Petroleum Explorationists (NAPE) Bulletin. 19: 61-77.

[63] Ojo, O. J., and Akande, S. O., (2008), Microfloral assemblage, age and paleoenvironment of the Upper Cretaceous Patti Formation, southern Bida Basin, Nigeria, Journal of Mining and Geology. 44: 71-78.https://doi.org/10.4314/jmg.v44i1.18885.

[64] Ojo, O. J., Adepoju, S. A., Adewole, T. M., and Abiola, A. O., (2011), Sedimentological and Geochemical Studies of Maastrichtian Clays in Bida Basin, Nigeria: Implication for Resource Potential. Centrepoint Journal (Science Edition). 17. (2): 71-88.

[65] Ojo, S. B., (1984), Middle Niger Basin Revisited, Magnetic constraints on Gravity Interpretations. Nigerian Mining and Geosciences Society Conference, Nsukka, Nigeria, Abstract. 52-53.

[66] Ojo, S. B., and Ajakaiye, D. E., (1989), Preliminary Interpretation of Gravity Measurements in the Mid - Niger Basin area Nigeria. In: Kogbe, C. A., (Ed.), Geology of Nigeria. 2nd Edition, Rock View (Nigeria) Limited Jos Nigeria, 347-358.

[67] Okoro, A. U., (2007), Lithofacies and Depositional Environments of the Bida Sandstones, Bida Basin Nigeria, Journal of Applied and Natural Sciences (JANS), 1. (1): 64-70.

[68] Okunlola, O.A., and Idowu, O., (2012), The Geochemistry of Claystone-Shale Deposits from the Maastritchian Patti Formation, Southern Bida Basin, Nigeria Earth Sciences, Resources, SJ. 16 (2): 57-67.

[69] Olabode, S.O., (2016), Soft Sediment Deformation Structures in the Maastrichtian Patti Formation, Southern Bida Basin Nigeria: Implications for the Assessment of Endogenic Triggers in the Maastrichtian Sedimentary Record, Open Journal of Geology, 6, 410-438. https://doi.org/10.4236/ojg.2016.66036.

[70] Olaniyan, O., and Olobaniyi, S. B., (1996), Facies Analysis of the Bida Sandstone Formation around Kajita, Nupe Basin Nigeria, J.Afr. Earth Sci. 23: 253-256.https://doi.org/10.1016/S0899-5362(96)00066-8.

[71] Omali, A.O., Imasuen, O.I. and Okiotor, M.E., (2011), Sedimentological Characteristics of Lokoja Sandstone Exposed at Mount Patti, Bida Basin, Nigeria, Advances in Applied Science Research.

[72] Oyinloye, A. O., (2011). Geology and Geotectonic Setting of the Basement Complex Rocks in SouthWestern Nigeria: Implications on Provenance and Evolution, InTech- Earth and Environmental Sciences- Dr. Imran Ahmad Dar (Ed.). 97-119. 
[73] Osokpor, J., and Okiti, J., (2013), Sedimentological and Paleodepositional Studies of Outcropping Sediments in Parts of Southern Middle Niger Basin, International Journal of Science and Technology (IJST), 12: 839-846.

[74] Osokpor, J., Okiti, J., Ekuerugbe, L. O., and Osokpor, O. J., (2013), Paleodepositional Environment and Sequence Stratigraphy of Outcropping Sediments in Parts of Southern Middle Niger Basin, Nigeria, Journal of Environmental and Earth Sciences. 3. (9): 152-170.

[75] Petters, S. W., (1986), Foraminiferal biofacies in the Nigerian rift and continental margin deltas. In Oti, M. N. and Postma, G. (Editor), Geology of Deltas. A. A. Balkema, Rotterdam. 219-235.

[76] Pettijohn, F. J., (1984), Sedimentary Rocks, Third Edition, CBS Publ. \& Distr. PVT, Ltd. New Delhi, India, 628p.

[77] Porter, E. P., (1978), Petrology and Chemistry of Modern Big River Sand. Journal of Geology. 86: 423-449.https://doi.org/10.1086/649711.

[78] Rahaman, M. A. O., Coker, S. J., Bale, R. B., Omada, I. J., Obaje, N. G., and Fadiya, S. L., (2017), Field Trip Guide to the Southern Bida Basin, 53rd Annual International Conference and Exhibitions, NMGS. 4p.

[79] Rahaman, M. A. O., Fadiya, S. L., Adekola, S. A., Coker, S. J., Bale, R. B., Olawoki, O. A., Omada, I. J., Obaje, N. G., Akinsape, O. T., Ojo, G. A., and Akande, W. G., (2019), A Revised Stratigraphy of the Bida Basin, Nigeria, Journal of African Earth Sciences, Elsevier. 151: 6781.https://doi.org/10.1016/j.jafrearsci.2018.11.016.

[80] Reed, S. R., and Mergner, J. I., (1945), Preparation of Rock Thin Sections. U. S. Geological Survey Report, Washington, D. C., 1184 - 1203. Retrieved from: http://www.mirisocam.org/ammin/am38/am38_1184.pdf.10/06/2015.

[81] Reyment, R. A., (1965), Aspects of the Geology of Nigeria: The Stratigraphy of the Cretaceous Cenozoic Deposits, Ibadan University Press. 145p.

[82] Sanni, Z. J., Toyin, A., Ibrahim, A. and Ayinla, H. A., (2016), Provenance Studies through Petrography and Heavy Mineral Analysis of Part of Agbaja-Lokoja Formation, Bida Basin, NW Nigeria, Ife Journal of Science. 18 (1) 203-212.

[83] Shao, J., and Yang, S., (2012), Does Chemical Index of Alteration (CIA) reflect Silicate Weathering and Monsoonal Climate in the Changjiang River Basin? Chinese Science Bulletin, Vol. 57, No.10: 1178-1187https://doi.org/10.1007/s11434-011-4954-5.

[84] Stow, D. A. V., (2005), Sedimentary Rocks in the Field: A Colour Guide, Manson Publishing Ltd, 73 Corringham Road London NW 11 7DL, UK. 320p.https://doi.org/10.1201/b15204.

[85] Suttner, L. J., Basu, A., and Mach, G. H., (1981), Climate and Origin of Quartz Arenites, Journal of Sedimentary Petrology. 5: $1235-1246$.

[86] Tucker, M. E., (1982), The Field Description of Sedimentary Rocks, Open University Press, John Wiley \& Sons, New York. 112p.

[87] Voicu, G., and Bardoux, M., (2002), Geochemical Behaviour under Tropical Weathering of the Barama-Mazaruni Greenstone Belt at Omai Gold Mine, Guyana Shield, Journal of Applied Geochemistry. 17:321-336.https://doi.org/10.1016/S0883-2927(01)00085-3.

[88] Voicu, G., Bardoux, M., Harnois, L., and Grepeau, R., (1997), Lithological and Geochemical Environment of Igneous and Sedimentary Rocks at Omai Gold Mine, Guyana, South America, Journal of Exploration and Mining geology. 6:153-170.

[89] Whiteman, A. (1982), Nigeria: Its Petroleum Geology, Resources and Potential. 1 \& 2 Graham and Trotman, London. 349p.https://doi.org/10.1007/978-94-009-7361-9_1.

[90] Wright, J. B., Hastings, D. A., Jones, W. B., and Williams, H. R., (1985), Geology and Mineral Resources of West Africa. George Allen and Unwin, London. 187.

[91] Zaborski, P. M., (1998), A Review of the Cretaceous System in Nigeria, African Geosciences. 5: 385-483.

[92] Zahid, K. M., and Barbeau, D. L., (2011), Constructing Sandstone Provenance and Classification Ternary Diagrams Using an Electric Spreadsheet, Journal of Sedimentary Research. 81: 702-707.https://doi.org/10.2110/jsr.2011.55. 